Prepared in cooperation with the Town of Newfield and the Tompkins County Planning Department

\title{
Geohydrology and Water Quality of the Stratified-Drift Aquifers in West Branch Cayuga Inlet and Fish Kill Valleys, Newfield, Tompkins County, New York
}

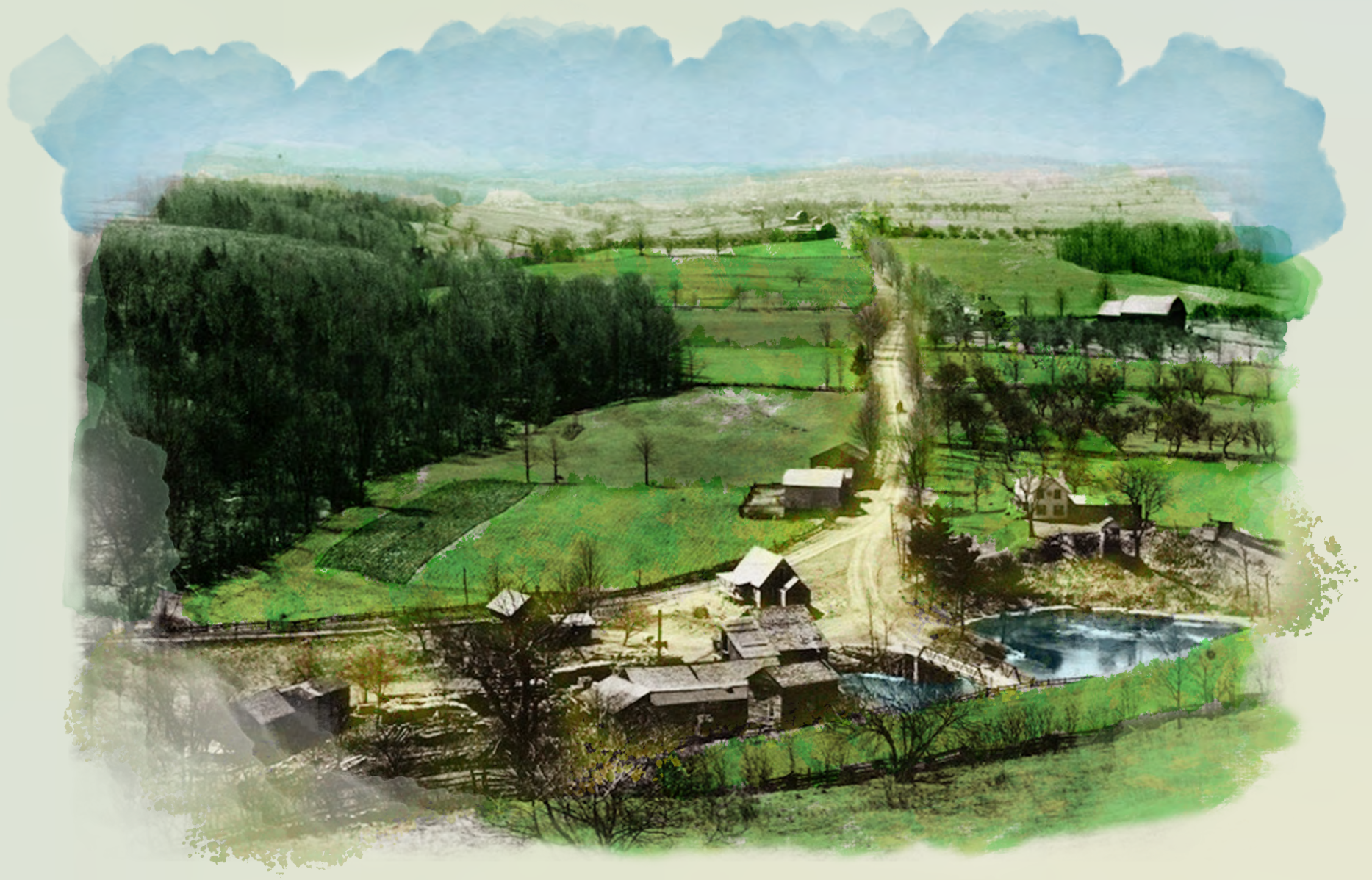

Scientific Investigations Report 2021-5064 
Cover. Village of Newfield, New York, looking south from between Protts Hill Road and Trumballs Corners Road above Bank Street; historical photograph courtesy of the Newfield Historical Society Archives. 


\section{Geohydrology and Water Quality of the Stratified-Drift Aquifers in West Branch Cayuga Inlet and Fish Kill Valleys, Newfield, Tompkins County, New York}

By Benjamin N. Fisher, Paul M. Heisig, and William M. Kappel

Prepared in cooperation with the Town of Newfield and the Tompkins County

Planning Department

Scientific Investigations Report 2021-5064 


\section{U.S. Geological Survey, Reston, Virginia: 2021}

For more information on the USGS - the Federal source for science about the Earth, its natural and living resources, natural hazards, and the environment—visit https://www.usgs.gov or call 1-888-ASK-USGS.

For an overview of USGS information products, including maps, imagery, and publications, visit https://store.usgs.gov/.

Any use of trade, firm, or product names is for descriptive purposes only and does not imply endorsement by the U.S. Government.

Although this information product, for the most part, is in the public domain, it also may contain copyrighted materials as noted in the text. Permission to reproduce copyrighted items must be secured from the copyright owner.

Suggested citation:

Fisher, B.N., Heisig, P.M., and Kappel, W.M., 2021, Geohydrology and water quality of the stratified-drift aquifers in West Branch Cayuga Inlet and Fish Kill Valleys, Newfield, Tompkins County, New York: U.S. Geological Survey Scientific Investigations Report 2021-5064, 42 p., https://doi.org/10.3133/sir20215064.

Associated data for this publication:

Fisher, B.N., and Keto, D.S., 2021, Geospatial datasets for the geohydrology and water quality of the stratified-drift aquifers in West Branch Cayuga Inlet/Fish Kill aquifers in Newfield, Tompkins County, New York: U.S. Geological Survey data release, https://doi.org/10.5066/P94Y3E81.

Fisher, B.N., and Keto, D.S., 2021, Horizontal-to-vertical spectral ratio and depth-to-bedrock for geohydrology and water quality of the stratified-drift aquifer in West Branch Cayuga Inlet and Fish Kill Valleys, Newfield, Tompkins County, New York, July 2011-November 2016: U.S. Geological Survey data release, https://doi.org/10.5066/ P9N6AZ4E.

ISSN 2328-0328 (online) 


\section{Acknowledgments}

The authors thank the Newfield Town Board for their support throughout the course of the study and the residents of the town who provided information or use of their wells for testing and monitoring. The authors also thank the Tompkins County Planning Department for their support for this and previous aquifer mapping projects in Tompkins County as part of the mapping under the Tompkins County Aquifer Program. A special thanks to Todd Miller (retired), Ed Bugliosi (retired), Lacey Pitman, Liz Kreitinger, Brett Hayhurst, Brian Breaker, Valerie Shao,

Erin Costello, and Carrie Gulvin of the U.S. Geological Survey for their assistance in the field with data collection. 



\section{Contents}

Acknowledgments ……...................................................................................................................

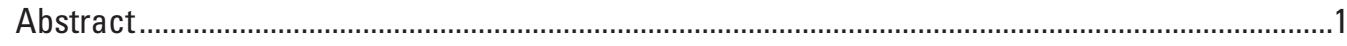

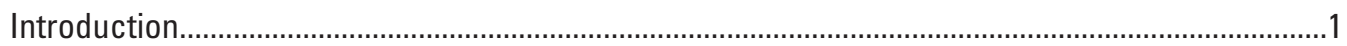

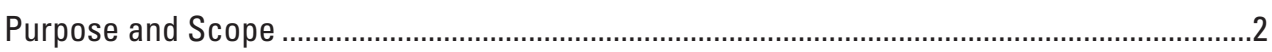

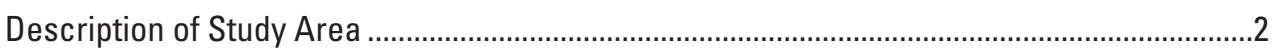

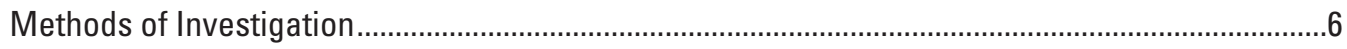

Surficial Geologic Data ................................................................................................

Well Inventory, Test Drilling, and Water-Level Measurements ..................................................6

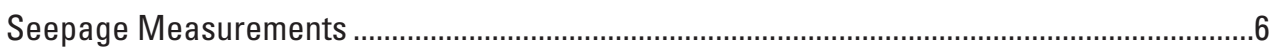

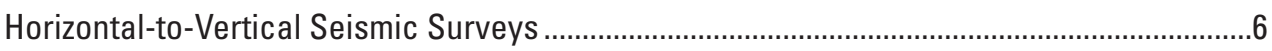

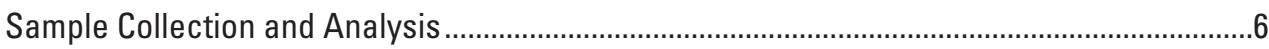

Depositional History and Framework of Glacial and Postglacial Deposits........................................

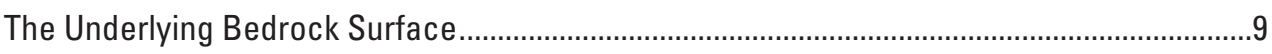

Glacial and Postglacial History .................................................................................................

The Valley Heads Readvance ...................................................................................

Deglaciation from the Valley Heads Ice Margin.............................................................12

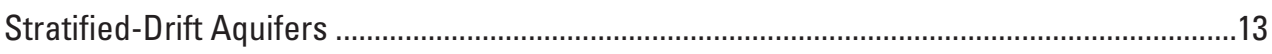

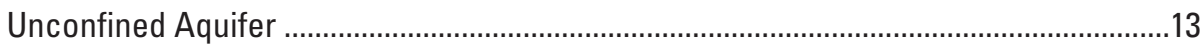

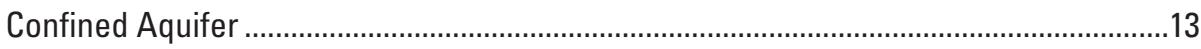

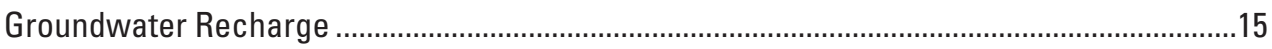

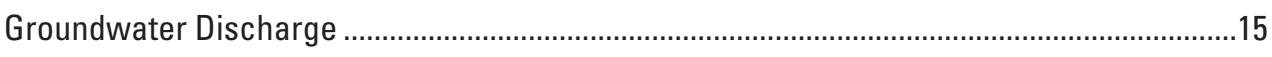

Quality of Surface Water and Groundwater in the Stratified-Drift Aquifer in Newfield ..................18

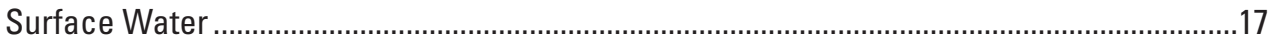

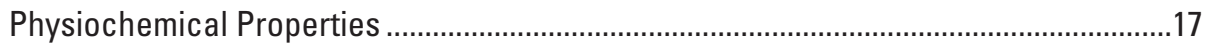

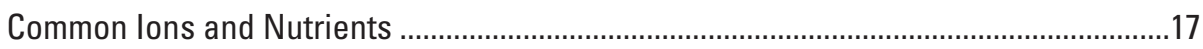

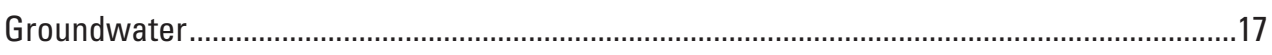

Physiochemical Properties ....................................................................................18

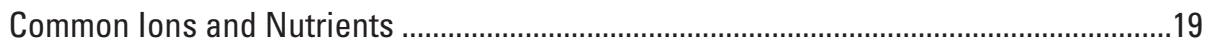

Radiochemical Activities................................................................................................19

Dissolved Atmospheric Gases and Chlorofluorocarbon-Derived Groundwater Age ....19

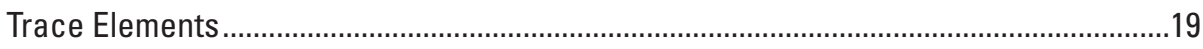

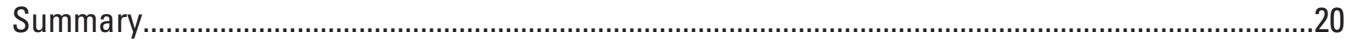

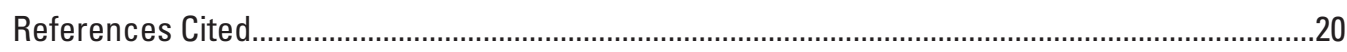

Appendix 1. Well Logs From Test Wells Drilled in the West Branch Cayuga Inlet and

Fish Kill Aquifer in Newfield, New York ...........................................................................31

Appendix 2. Test Well Hydrographs in the West Branch Cayuga Inlet and Fish Kill Valleys in Newfield, New York ........................................................................................37

Appendix 3. Groundwater Samples Collected in the West Branch Cayuga Inlet and Fish Kill Valleys in Newfield, New York 


\section{Figures}

1. Map showing physiographic features of New York and location of the West Branch Cayuga Inlet and Fish Kill Valley study areas in the town of Newfield, Tompkins County, New York

2. Map showing location of stratified-drift (unconsolidated) aquifers in Tompkins County, New York.

3. Map showing locations of surface-water-quality sites, aquifer boundaries, and valleys in Newfield, New York

4. Map showing locations of domestic, U.S. Geological Survey monitoring, and production wells in Newfield, New York

5. Map showing locations of horizontal-to-vertical spectral ratio seismic method surveys in Newfield, New York.

6. Map showing bedrock altitude contour lines in the West Branch Cayuga Inlet and Fish Kill Valleys in Newfield, New York

7. Hydrogeologic cross sections in Newfield, New York

8. Map showing surficial geology, aquifer boundaries, wells, drainage divides, ice margins, eskers, and geologic cross sections in Newfield, Tompkins County, New York

9. Map showing locations of seepage synoptic surface water sites in in Newfield, Tompkins County, New York

\section{Tables}

1. Discharge measurements made on selected streams in the West Branch Cayuga Inlet and Fish Kill Valleys, Newfield, Tompkins County, New York

2. Groundwater withdrawals in the West Branch Cayuga Inlet and Fish Kill Valleys in Newfield, New York, in 2012

3. Physical properties and concentrations of common ions and nutrients in surface-water samples from West Branch Cayuga Inlet and Fish Kill, Newfield, Tompkins County, New York

\section{Conversion Factors}

U.S. customary units to International System of Units

\begin{tabular}{lll}
\hline \multicolumn{1}{c}{ Multiply } & \multicolumn{1}{c}{ By } & \multicolumn{1}{c}{ To obtain } \\
\hline foot $(\mathrm{ft})$ & 0.3048 & meter $(\mathrm{m})$ \\
mile $(\mathrm{mi})$ & 1.609 & kilometer $(\mathrm{km})$ \\
square mile $\left(\mathrm{mi}^{2}\right)$ & 2.590 & square kilometer $\left(\mathrm{km}^{2}\right)$ \\
gallon (gal) & 3.785 & liter $(\mathrm{L})$ \\
cubic foot per second $\left(\mathrm{ft}^{3} / \mathrm{s}\right)$ & 0.02832 & cubic meter per second $\left(\mathrm{m}^{3} / \mathrm{s}\right)$ \\
gallon per second $(\mathrm{gal} / \mathrm{s})$ & 0.264172 & liter per second $(\mathrm{L} / \mathrm{s})$ \\
gallon per day $(\mathrm{gal} / \mathrm{d})$ & 0.003785 & cubic meter $\mathrm{per} \mathrm{day}\left(\mathrm{m}^{3} / \mathrm{d}\right)$ \\
\hline
\end{tabular}

Temperature in degrees Celsius $\left({ }^{\circ} \mathrm{C}\right)$ may be converted to degrees Fahrenheit $\left({ }^{\circ} \mathrm{F}\right)$ as ${ }^{\circ} \mathrm{F}=\left(1.8 \times{ }^{\circ} \mathrm{C}\right)+32$.

Temperature in degrees Fahrenheit $\left({ }^{\circ} \mathrm{F}\right)$ may be converted to degrees Celsius $\left({ }^{\circ} \mathrm{C}\right)$ as ${ }^{\circ} \mathrm{C}=\left({ }^{\circ} \mathrm{F}-32\right) / 1.8$. 


\section{Datum}

Vertical coordinate information is referenced to the North American Vertical Datum of 1988 (NAVD 88).

Horizontal coordinate information is referenced to the North American Datum of 1983 (NAD 83).

Altitude, as used in this report, refers to distance above the vertical datum.

\section{Supplemental Information}

Specific conductance is given in microsiemens per centimeter at 25 degrees Celsius $(\mu \mathrm{S} / \mathrm{cm}$ at $\left.25^{\circ} \mathrm{C}\right)$.

Concentrations of chemical constituents in water are given in either milligrams per liter (mg/L) or micrograms per liter $(\mu \mathrm{g} / \mathrm{L})$.

Activities for radioactive constituents in water are given in picocuries per liter (pCi/L).

\section{Abbreviations}

$\begin{array}{ll}\text { EPA } & \text { U.S. Environmental Protection Agency } \\ \text { HVSR } & \text { horizontal-to-vertical spectral ratio } \\ \text { lidar } & \text { light detection and ranging } \\ \text { MCL } & \text { maximum contaminant level } \\ \text { NWQL } & \text { National Water Quality Laboratory } \\ \text { SMCL } & \text { secondary maximum contaminant level } \\ \text { USGS } & \text { U.S. Geological Survey }\end{array}$





\title{
Geohydrology and Water Quality of the Stratified-Drift Aquifers in West Branch Cayuga Inlet and Fish Kill Valleys, Newfield, Tompkins County, New York
}

\author{
By Benjamin N. Fisher, Paul M. Heisig, and William M. Kappel
}

\section{Abstract}

From 2011 to 2016, the U.S. Geological Survey, in cooperation with the Town of Newfield and the Tompkins County Planning Department, performed a study of the stratified-drift aquifers in the West Branch Cayuga Inlet and Fish Kill Valleys in Newfield, Tompkins County, New York. Both confined and unconfined aquifers were identified, mostly in the valleys. The confined aquifer consists of a discontinuous sand and gravel layer that overlies bedrock and is commonly confined by overlying fine-grained sediments. The unconfined aquifer consists of surficial ice contact sand and gravel, alluvial silt, sand and gravel, and areas where several large tributary streams deposited alluvial fans in the valley, all of which were deposited during and after the last glacial recession.

The unconfined aquifers are primarily recharged by direct infiltration of precipitation at the land surface, by surface runoff and shallow subsurface flow from adjacent hillsides, and by seepage loss from streams crossing the aquifer, especially on alluvial fans. The confined aquifers are primarily recharged by groundwater stored in the overlying sand and gravel aquifer that slowly seeps downward through the underlying confining layer. Other sources of recharge are precipitation that falls directly on the surficial confining unit and adjacent valley walls, which then slowly seeps downward and enters the confined aquifer, and groundwater flow from bordering till and bedrock and from bedrock below the valley. There may also be some recharge where confining units are absent or where parts of the confining units contain sediments with moderate permeability.

The groundwater naturally discharges to the Fish Kill and West Branch Cayuga Inlet streams and to wetlands overlying the aquifer boundaries, with additional losses due to evapotranspiration. Groundwater is pumped from the aquifers by domestic, municipal, and agricultural wells. Approximately 57.9 million gallons per year was withdrawn from the stratified-drift (sand and gravel) aquifers.

Groundwater samples were collected from 11 wells, and surface water samples were collected at 2 sites, one each from Fish Kill and West Branch Cayuga Inlet. None of the common ions (for example, sodium, chloride, and magnesium) exceeded existing drinking water standards at either surface water site. The concentration of nitrate plus nitrite detected was 0.4 milligram per liter as nitrogen in the West Branch Cayuga Inlet site. Total phosphorus was detected at 0.01 milligram per liter as phosphate for both sites. Of the 11 wells sampled, 8 were finished in confined sand and gravel aquifers, 1 was finished in unconfined sand and gravel, and 2 were finished in shale bedrock. Groundwater quality in the study area generally met Federal and State drinking-water standards. However, of the 11 samples taken, 2 exceeded the U.S. Environmental Protection Agency drinking water advisory taste threshold of 20 milligrams per liter for sodium, 8 exceeded the secondary maximum contaminant level of 300 micrograms per liter for iron, and 9 exceeded the secondary maximum contaminant level of 50 micrograms per liter for manganese.

\section{Introduction}

In 2000, the U.S. Geological Survey (USGS) mapped the extent of the stratified-drift (sand and gravel) aquifers in Tompkins County, New York (Miller, 2000). In 2000-02, the USGS, in cooperation with Tompkins County Planning Department, used this information to start a detailed study of the geohydrologic properties of the 17 stratified-drift aquifers in Tompkins County. The purpose of these studies was to provide town and county planners with detailed information needed to manage, maintain, and protect groundwater resources. The extent of the stratified-aquifers aquifers was based mostly on natural hydrologic boundaries, but in some cases, political boundaries were used as well. The stratifieddrift aquifers within the West Branch Cayuga Inlet and Fish Kill Valleys, the sixth of the 17 study areas to be investigated (Miller and Karig, 2010; Miller and Bugliosi, 2013; Bugliosi and others, 2014; Miller, 2015; Fisher and others, 2019), were studied during 2011-16.

Evaluation, development, and protection of these aquifers require information on the aquifer geometry (the threedimensional extent and distribution of glacial sediments, including aquifers and confining units), sources of recharge 
and discharge, and aquifer water quality. Samples were collected from wells to characterize the chemical quality of groundwater and to determine its suitability for drinking water. Groundwater samples were collected from wells finished in unconfined and confined stratified-drift and bedrock aquifers. In addition, stream samples were collected to characterize the chemical quality of surface water under base-flow conditions (when the flow is mostly from groundwater discharging into stream channels) and to determine whether there are similarities in water quality between surface water and groundwater.

\section{Purpose and Scope}

The purpose of this report is to describe the geohydrology and water quality of the stratified-drift aquifers in the West Branch Cayuga Inlet and Fish Kill Valleys in Newfield, Tompkins County, New York. The report also describes and illustrates (1) the surficial geology of the study area, including the geologic framework of the aquifer system and geohydrologic sections; (2) the groundwater-flow system, including information about groundwater levels, groundwater to surface-water interaction, and recharge and discharge conditions; and (3) groundwater and surface-water quality, including information about concentrations of common inorganic ions (such as chloride and sodium), species of nitrogen and phosphorus compounds (collectively referred to as nutrients), and trace elements.

\section{Description of Study Area}

The West Branch Cayuga Inlet and Fish Kill Valleys are in the Appalachian Plateau physiographic province. The plateau is characterized by hills and valleys that resulted from millions of years of dissection by southerly flowing streams that were subsequently modified by several periods of glaciation (fig. 1). Bedrock in the area consists of Upper Devonian interbedded shales and siltstones of the Sonyea and West Falls Formations (Rickard and Fisher, 1970). These units regionally dip (about 40 to 60 feet per mile) to the south, with gentle east- and northeast-trending folds also present with similar dips (Williams and others, 1909; Wedel, 1932).

The stratified-drift aquifer in the West Branch Cayuga Inlet and Fish Kill Valleys is one of two stratified-drift aquifers in Newfield. These two valleys drain northward to Cayuga Lake; the other part of the aquifer system in Newfield is in the Cayuta Inlet and Pony Hollow Valleys, which are tributaries to the Susquehanna River basin (not shown) in the southwestern part of Newfield (fig. 2) and were studied previously by Miller and Pittman (2012) and Bugliosi and others (2014). The study area covers approximately 20.4 square miles $\left(\mathrm{mi}^{2}\right)$. The boundaries of the unconfined and confined aquifer cover about $1.92 \mathrm{mi}^{2}$ and $3.07 \mathrm{mi}^{2}$, respectively. Within the study area, the drainage areas of Fish Kill and West Branch Cayuga Inlet cover about $8.03 \mathrm{mi}^{2}$ and $7.38 \mathrm{mi}^{2}$, respectively.

The current study area is comprised of three connected valleys (fig. 3): a 2.5-mile (mi)-long Connecticut Hill Road Valley in the northwestern part of Newfield that drains into Fish Kill, the 2.4-mi-long Fish Kill Valley from its headwaters near the intersection of Sebring Road and Trumbull Corners Road to the boundary between Newfield and Enfield where the aquifer ends at a bedrock gorge, and the 3.2-mi-long West Branch Cayuga Inlet Valley that drains northeastward from its headwaters at the Valley Heads moraine through Newfield hamlet (fig. 3) and thence eastward into the Cayuga Inlet Valley, which drains to Cayuga Lake at Ithaca. Altitudes in the study area range from about 1,940 feet (ft; North American Vertical Datum of 1988 [NAVD 88]) on the highest hilltop, Doll Hill, which is southwest of Newfield hamlet, to about $830 \mathrm{ft}$ where West Branch Cayuga Inlet enters the Cayuga Inlet Valley east of Newfield hamlet. The valley bottoms east of Newfield are underlain by unconfined and confined aquifers in glacial deposits in many places. 


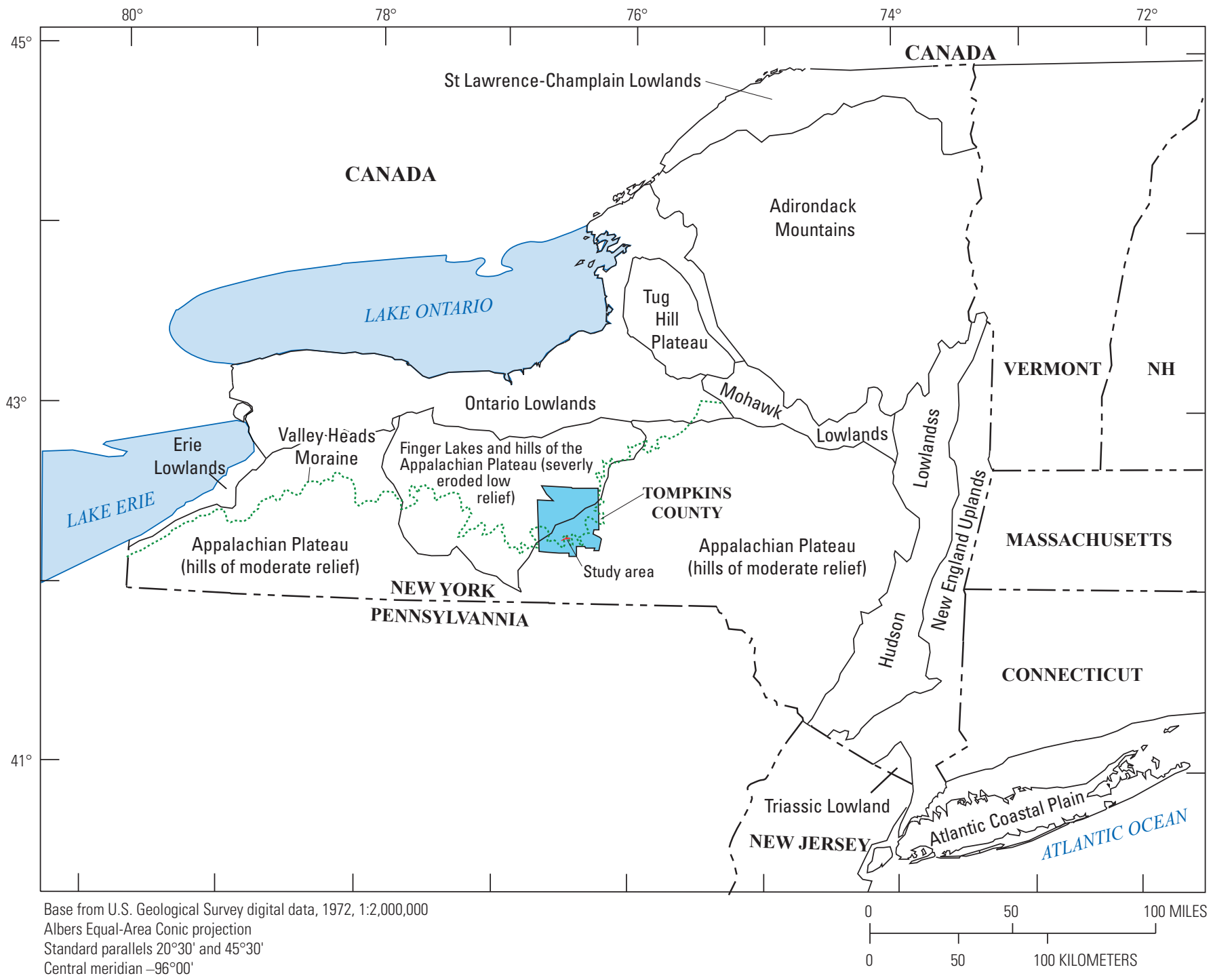

Figure 1. Map showing physiographic features of New York and location of the West Branch Cayuga Inlet and Fish Kill Valley study areas in the town of Newfield, Tompkins County, New York. 


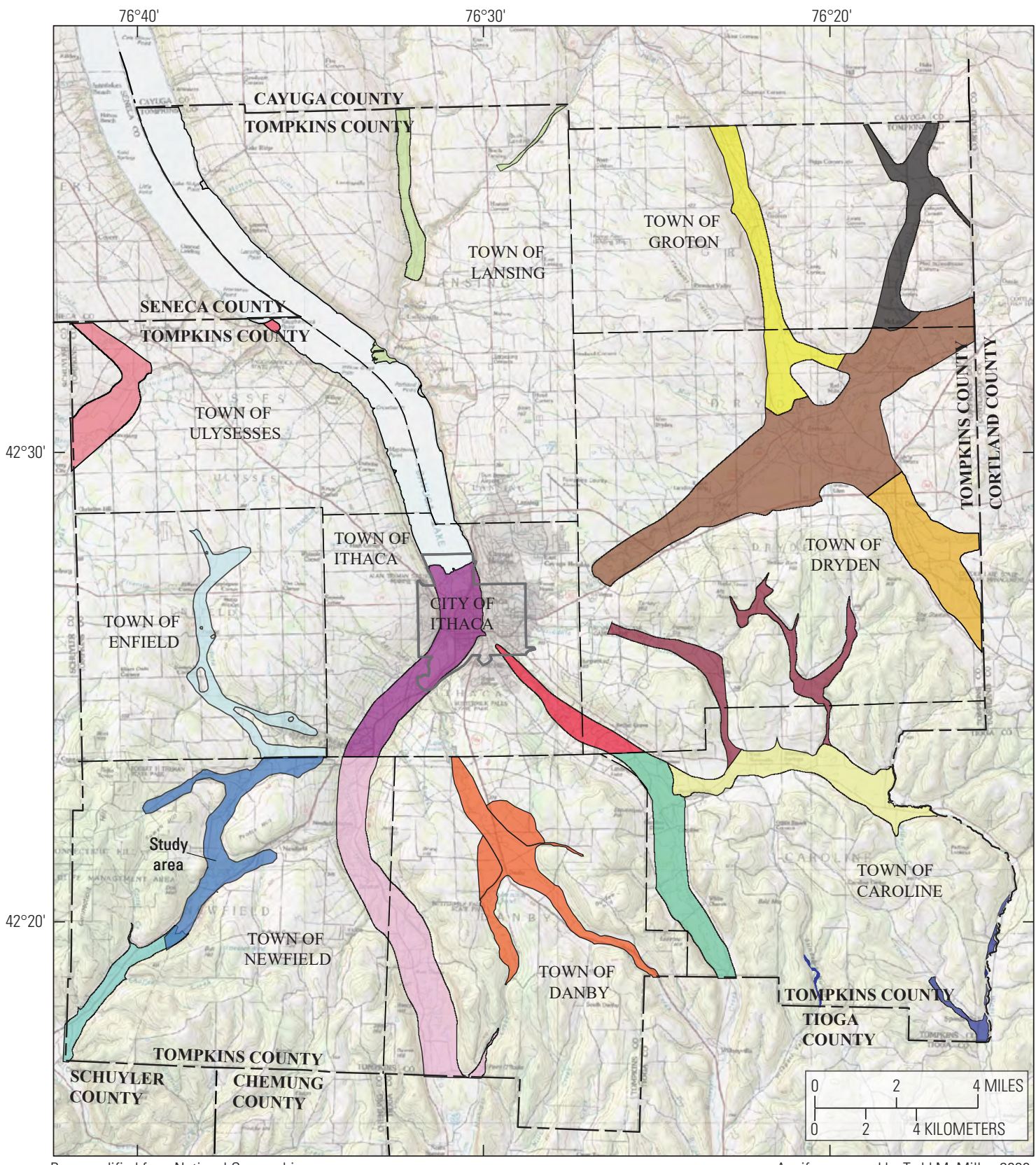

Base modified from National Geographic Topo Maps, 1:100,000, 2003

Aquifer reach

\section{EXPLANATION}

Cascadilla Creek Valley and upland Sixmile Creek Valley Enfield Creek Valley (Fisher and others, 2019) Lower Cayuga Inlet trough

Lower Fall Creek Valley

Lower Sixmile Creek trough (towns of Dryden and Ithaca) Lower Sixmile Creek and Willseyville Creek trough (Miller and Karig, 2010)

Owasco Inlet Valley

Pony Hollow Valley (Bugliosi and others, 2014)

Salmon Creek and Locke Valleys and Myers Point
Taughannock Creek Valley and Taughannock delta Upper Buttermilk Creek and Danby Creek Valleys (Miller, 2015) Upper Cayuga Inlet trough

Upper Fall Creek Valley

Upper Sixmile Creek and West Branch Owego Creek Valleys Virgil Creek Valley (Miller and Bugliosi, 2013)

West Branch Cayuga Inlet and Fish Kill Valleys (study area)

West Branch Owego Creek Valley and tributaries

Figure 2. Map showing location of 17 stratified-drift (unconsolidated) aquifers in Tompkins County, New York. 

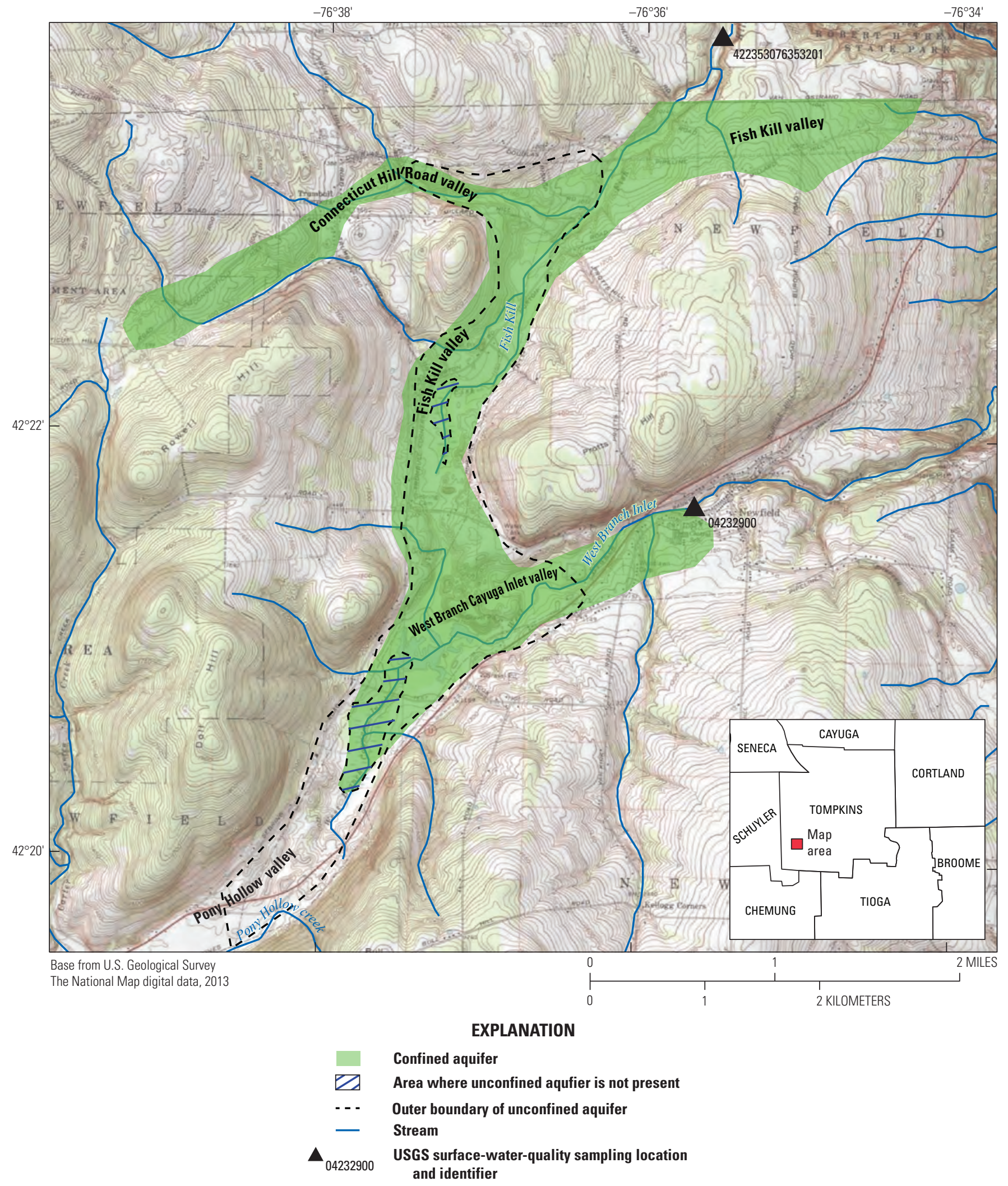

Figure 3. Map showing locations of surface-water-quality sites, aquifer boundaries, and valleys in Newfield, New York. USGS, U.S. Geological Survey. See also Fisher and Keto (2021a). 


\section{Methods of Investigation}

New and existing data were compiled for this study. New data included surficial geologic mapping, test drilling, seismic surveys, groundwater-level measurements, and surface-water and groundwater-quality sampling. Existing data included driller well records, and past geologic, soil, and surficial- and bedrock-deposit maps and reports.

\section{Surficial Geologic Data}

Surficial geology and aquifer distribution in this report are based on interpretation of a county soils map (Neely, 1961), a regional-scale map of surficial geology (Muller and Cadwell, 1986), topographic maps, orthophotographs, and localized data that included geologic mapping, water-well records, test wells drilled for this study, and horizontal-tovertical spectral ratio (HVSR) seismic surveys. The seismic surveys were used to determine the thickness of unconsolidated deposits and the altitude of the bedrock surface.

\section{Well Inventory, Test Drilling, and Water-Level Measurements}

A total of 131 well records were compiled for Newfield (fig. 4; U.S. Geological Survey, 2019). Sources of well data include previously published USGS groundwater studies, the USGS National Water Information System (NWIS), and well records obtained from the New York State Department of Environmental Conservation Water Well Drillers Registration Program. These data are available in Fisher and Keto (2021a). In addition, seven monitoring wells, two being within a dual completion well, were installed by the USGS for the purpose of better understanding the underlying aquifer material and depth to bedrock (fig. 4; table 1.1; U.S. Geological Survey, 2019).

Sediment samples were obtained from the USGS monitoring wells during drilling to help determine the composition of aquifer materials. Water-level and water-temperature data were collected at seven USGS monitoring wells and two domestic wells. Water-level data loggers were installed in each of these wells to monitor seasonal water level fluctuation (table 1.1). The loggers were set to record water level and water temperature data every 4 hours from which graphical representations of water level changes were made (table 2.1).

Altitudes of land surface at wells were estimated using light detection and ranging (lidar) technology and $1: 24,000$-scale topographic contour maps that were accurate to $0.5 \mathrm{ft}$ and $5 \mathrm{ft}$, respectively. Using these altitude data, depths to water below the measuring points were then converted to water-level altitudes.

\section{Seepage Measurements}

Synoptic streamflow seepage measurements (Rantz and others, 1982) were collected during base flow, that is, sustained low-flow conditions in the absence of precipitation, and the resulting surface runoff at 11 sites along West Branch Cayuga Inlet and 7 sites along Fish Kill to determine if these streams were losing or gaining groundwater from the aquifer. These seepage synoptic measurements were collected from August 31 through September 1, 2016.

\section{Horizontal-to-Vertical Seismic Surveys}

The HVSR or passive-seismic method is a technique of measuring ambient seismic noise to indirectly determine the thickness of the overburden (unconsolidated deposits) overlying bedrock (Lane and others, 2008). The presence of a significant thickness of till, especially dense till, results in depth-to-bedrock estimates that are too shallow. Thus, inferred bedrock depth in hydrogeologic sections may differ from calculated depths based on the published curve used in this study. Seismic surveys were done at 61 locations throughout the West Branch Cayuga Inlet and Fish Kill aquifer system to help determine the thickness of the overburden deposits (fig. 5). These data are available in Fisher and Keto (2021b).

\section{Sample Collection and Analysis}

Samples for this study were collected from groundwater and surface-water sites. Surface-water and groundwater samples collected for physiochemical properties, nutrients, common ions, and trace elements were analyzed at the USGS National Water Quality Laboratory (NWQL) in Denver, Colorado. Groundwater samples collected for tritium, dissolved atmospheric gases, and chlorofluorocarbons (CFCs) for the determination of the apparent age of groundwater were analyzed at the USGS Reston Groundwater Dating Laboratory in Reston, Virginia. Field parameters (temperature, specific conductance, $\mathrm{pH}$, and dissolved oxygen) were measured in place during sampling using a YSI Inc. multiparameter meter.

Water samples were collected from each well before it went through any type of filtration or chemical treatment system. All sampling and sample analysis were done in accordance with published techniques and methods (Busenberg and Plummer, 2008; U.S. Geological Survey, 2012).

Two surface-water samples were collected on November 19, 2012. Groundwater samples were collected during two periods over the duration of the study. Two groundwater samples were collected from Town of Newfield production wells on August 30 and November 19, 2012, and three domestic wells were sampled on November 20, 2012. Six additional groundwater samples were collected from the USGS monitoring wells on July 30, 2015. Altogether, 1 quality control (QC) sample and 11 environmental groundwater samples were collected. Nonflowing wells were purged until physiochemical properties (temperature, specific conductance, $\mathrm{pH}$, and dissolved oxygen) stabilized. 


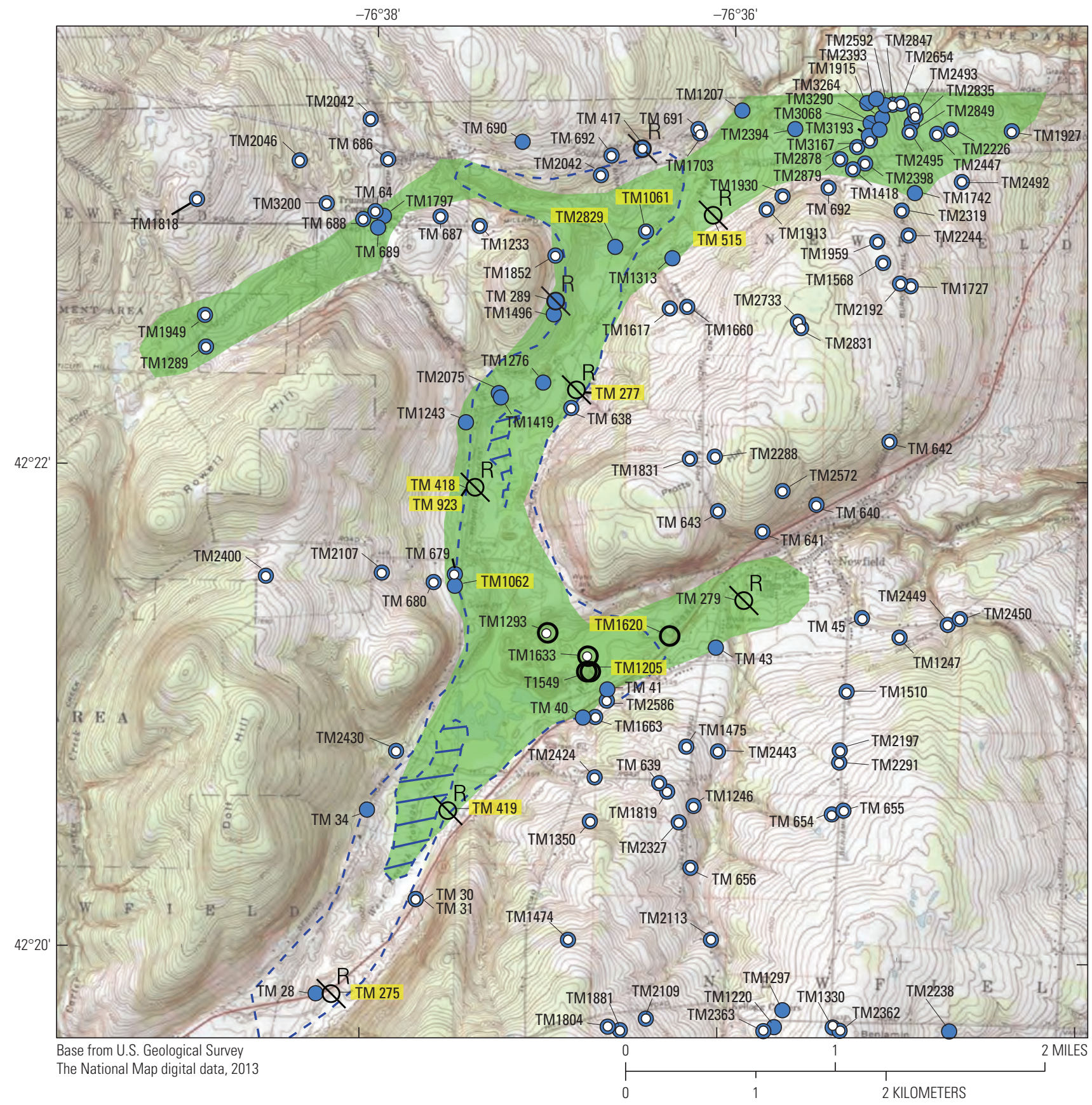

EXPLANATION
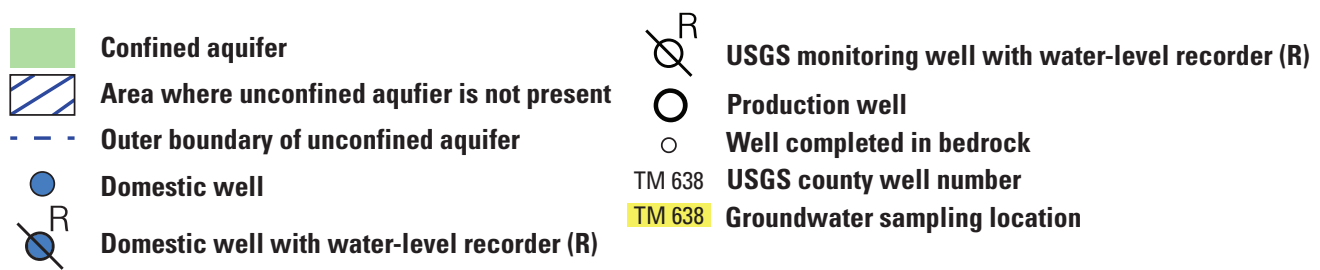

Figure 4. Map showing locations of domestic, U.S. Geological Survey (USGS) monitoring, and production wells in Newfield, New York, and the extent of unconfined and confined aquifers in glacial deposits in the study area and adjacent uplands. See also Fisher and Keto (2021a). 


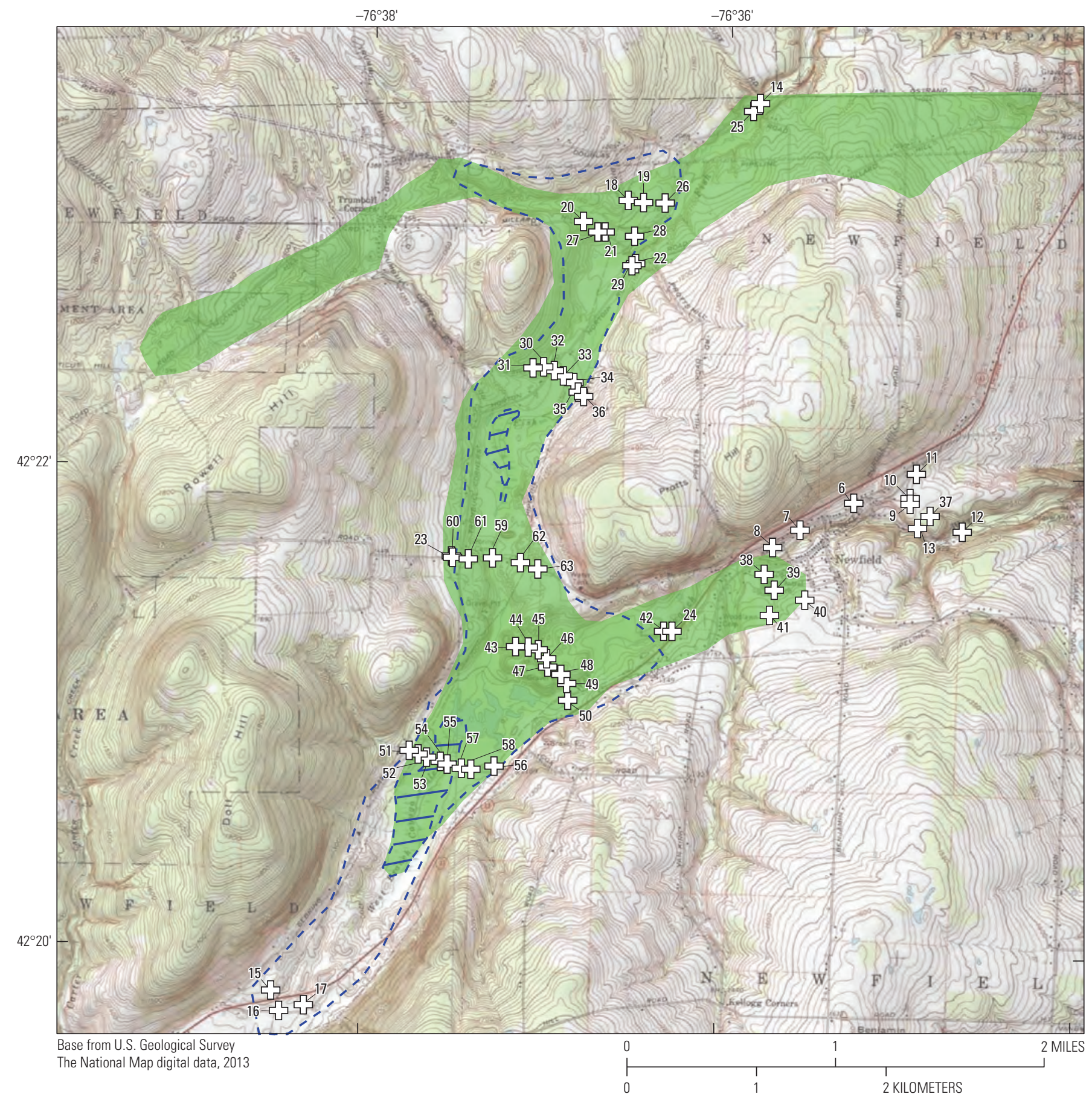

\section{EXPLANATION}

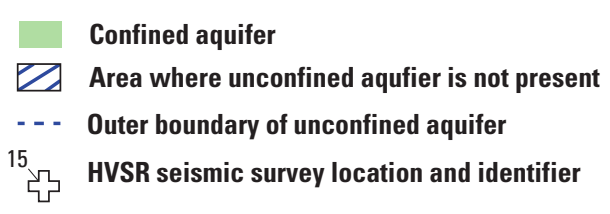

Figure 5. Map showing locations of horizontal-to-vertical spectral ratio (HVSR) seismic method surveys in Newfield, New York. See also Fisher and Keto (2021b). 


\section{Depositional History and Framework of Glacial and Postglacial Deposits}

The Newfield area has been subject to several periods of glaciation separated by interglacial (ice-free) periods during the Pleistocene Epoch, from about 2.6 million years ago to about 12,000 years ago (Fullerton, 1980). Since then, the glacial deposits that blanket the region have been locally modified (eroded and redeposited as postglacial deposits) by running water and by mass movement down steep, unstable slopes.

\section{The Underlying Bedrock Surface}

Unconsolidated deposits in the study area overlie shale and siltstone bedrock that has been eroded during glacial and intervening ice-free periods (fig. 6). Williams and others (1909) recognized that glacial erosion of bedrock was most profound in the deepest valleys where the ice was thickest and where the valley was aligned with regional ice movement, such as the Cayuga Inlet Valley (fig. 2). The depth to bedrock in this valley south of Ithaca is at least $350 \mathrm{ft}$ below land surface and probably as much as $450 \mathrm{ft}$ (Lawson, 1977). Erosion by glacial ice was not as effective in upland areas where ice was thinnest and flow weakest, especially where those valleys were oriented subparallel to or athwart ice flow in the nearest major valley or protected by bedrock hills. Valley fill within the highest altitude valleys (Fish Kill and Connecticut Hill Road Valleys; fig. 3) is as much as $150 \mathrm{ft}$ thick but is generally less than $100 \mathrm{ft}$ thick. Thicknesses within the lower west to east section of the more incised West Branch Cayuga Inlet Valley exceed $150 \mathrm{ft}$.

All tributary valleys to Cayuga Inlet valley are termed "hanging valleys" because the bedrock floor of the inlet valley has been eroded far below the bedrock floors of the tributary valleys. For example, the West Branch Cayuga Inlet floodplain, before it starts to incise near its junction with the Cayuga Inlet Valley, is more than $500 \mathrm{ft}$ higher than the Cayuga Inlet floodplain at their confluence; the difference in altitude of the bedrock floors of the West Branch versus the main Cayuga Inlet Valley is greater still. Such differences in altitude have resulted in the incision of narrow gorges in the bedrock along the Cayuga Inlet Valley walls during interglacial intervals (Williams and others, 1909; Miller and Karig, 2010; Karig, 2015; Miller, 2015). The gorges were buried during subsequent glacial advances and have been re-excavated to varying degrees during the past 12,000 years. In the study area, the West Branch Cayuga Inlet has been minimally incised into an inferred buried gorge south of the current [2021] stream channel (figs. 6 and 7; fig. 7 at back of report). Glacial and postglacial deposits have deflected the stream to the northern side of the valley near Newfield hamlet, where it flows on or close to the bedrock surface. Toward the bottom of the Cayuga Inlet Valley wall, the stream cascades over bedrock, but not in a pronounced gorge. In contrast, just north of the study area, Enfield Creek has re-excavated much of an earlier gorge at Enfield Glen. One probable reason for this disparity in incision is that the Enfield Creek drainage area is three times larger than that of the West Branch Cayuga Inlet.

\section{Glacial and Postglacial History}

Most glacial deposits within the study area are derived from two Laurentide ice sheet advances and retreats during the Late Wisconsin substage at the end of the Pleistocene Epoch. These include the maximum Late Wisconsin ice advance that completely covered the study area and extended south into Pennsylvania (Nissouri stade, from about 23,000 to 16,500 years before present; Muller and Calkin, 1993), and the Valley Heads readvance (Fairchild, 1932), which deposited moraines mostly in the form of outwash heads in valleys within the study area and across much of western New York (Port Bruce stade, which started about 15,500 years before present and continued until ice left the area about 14,400 years ago; Karrow, 1984; Cadwell and Muller, 2004). As a result, two (or more) tills are common in valleys north of the Valley Heads moraine (for example, Miller, 2015). Pre-late-Wisconsin glacial or interglacial deposits have been noted within the region, most commonly as gorge fillings (for example, Karig, 2015).

The surficial unconsolidated depositional features in the West Branch Cayuga Inlet, Fish Kill, and Connecticut Hill Road Valleys (fig. 3) are the result of deposition of kame moraines and associated deposits at the peak of the Valley Heads readvance and as the readvanced ice thinned and downwasted, as well as of erosion of the recently deglaciated landscape and deposition of floodplain alluvium, alluvial fans, and organic deposits. As the ice sheet readvanced into the Newfield area to the Valley Heads ice margin, previous deposits from the Wisconsin glacial maximum and postglacial deposits from the interglacial interval were overridden or partly eroded by the ice. In upland areas not covered by the Valley Heads ice, bedrock is mantled by till from the Wisconsin glacial maximum. Weak erosion by advancing glacial ice and limited meltwater volume during ice retreat in high-altitude valleys has resulted in thin valley-fill deposits relative to those in the main valleys. Some sediments in deep valley fill may be from ice advances before the Valley Heads advance.

\section{The Valley Heads Readvance}

The Valley Heads ice readvance occupied all the large valleys and some uplands within the study area, as indicated by morainal deposits in the Pony Hollow, Fish Kill, and Connecticut Hill Road Valleys (figs. 3 and 8; Williams and others, 1909; Denny and Lyford, 1963). The most well-defined position of the Valley Heads moraine is in Pony Hollow at the southern edge of the study area (Williams and others, 1909; 


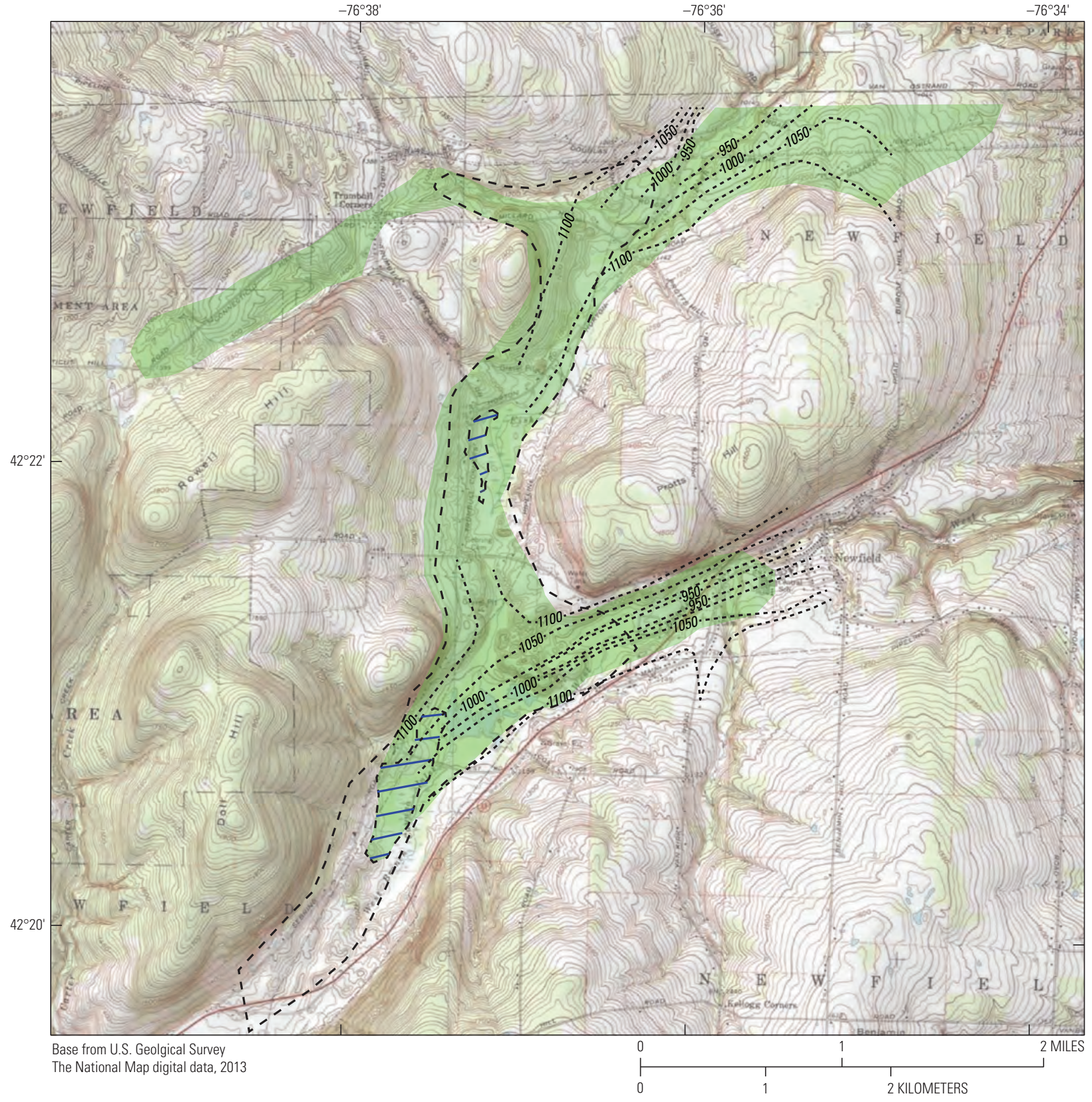

EXPLANATION

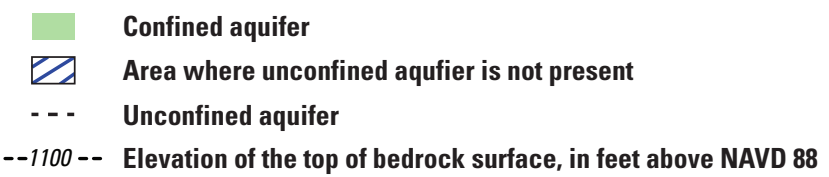

Figure 6. Map showing bedrock altitude contour lines in the West Branch Cayuga Inlet and Fish Kill Valleys in Newfield, New York. NAVD 88, North American Vertical Datum of 1988. 


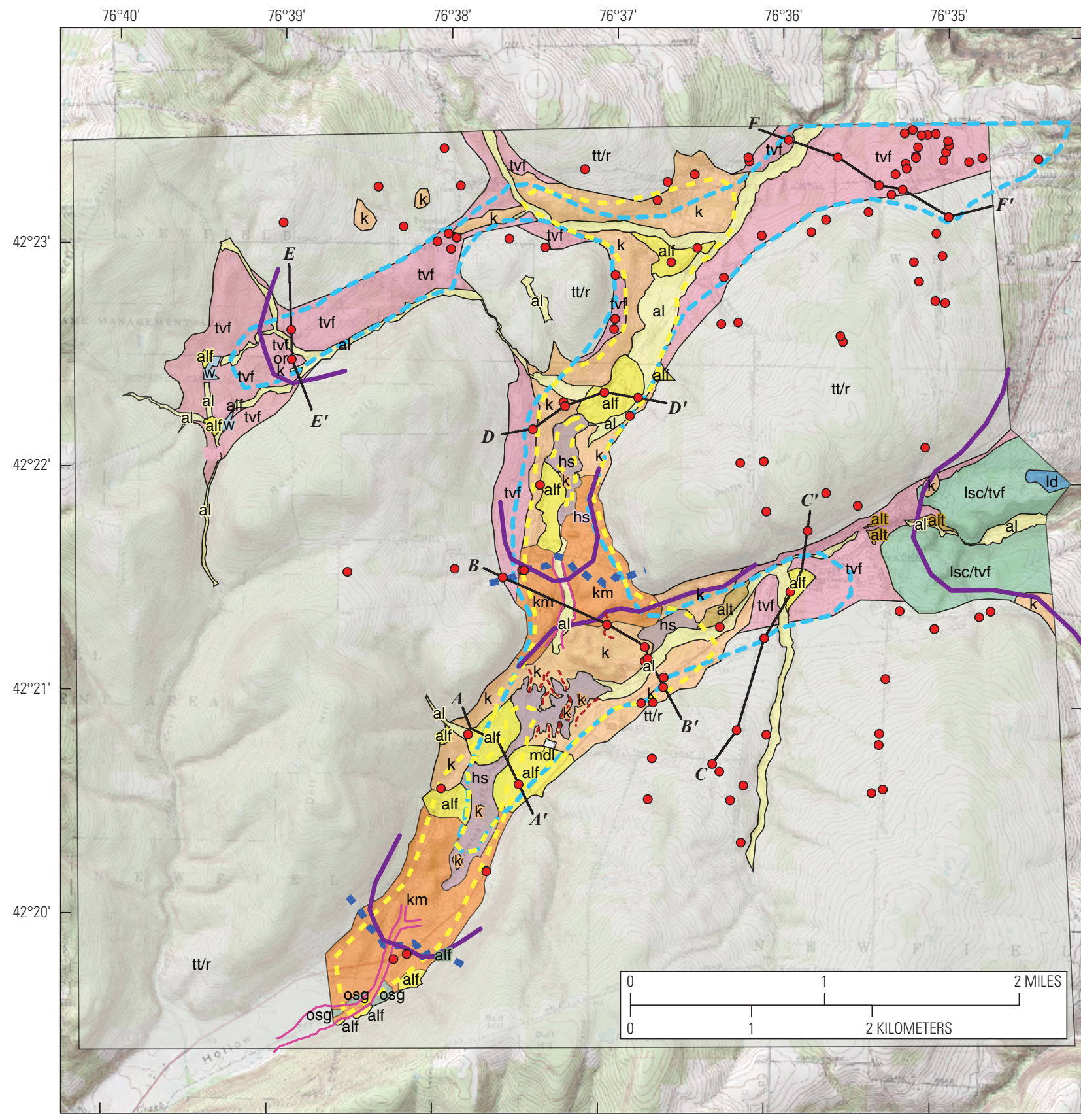

Base from U.S. Geological Survey

The National Mad digital data, 2013

\begin{tabular}{|c|}
\hline al \\
\hline \hline alf \\
\hline \hline alt \\
\hline \hline hs \\
\hline \hline Id \\
\hline Isc/tvf \\
\hline
\end{tabular}

\section{Channel and flood-plain alluvium}

Alluvial-fan deposit

Alluvial terrace

Fresh water swamp deposit

Delta deposit

Lacustrine silt and clay over ground-moraine deposit in valley till

\begin{tabular}{|r|l}
\hline tvf & Ground-moraine deposit in valley till (valley facies) \\
\hline \multicolumn{1}{|c|}{ osg } & Outwash sand and gravel \\
\hline $\mathrm{r}$ & Kame \\
\hline $\mathrm{km}$ & Kame moraine deposit \\
\hline $\mathrm{mdl}$ & Manmade land \\
\hline $\mathrm{w}$ & Water \\
\hline
\end{tabular}

Figure 8. Map showing surficial geology, aquifer boundaries, wells, drainage divides, ice margins, eskers, and geologic cross sections in Newfield, Tompkins County, New York. See also Fisher and Keto (2021a). 
Fairchild, 1932; Denny and Lyford, 1963; Bugliosi and others, 2014). This moraine forms the present-day divide between the Pony Hollow Creek drainage to the south (Susquehanna River Basin) and the West Branch Cayuga Inlet to the north (St. Lawrence River Basin). It features kame-moraine deposits that transition southward to an outwash head and valley train that continues for the entire length of the Pony Hollow Valley (Bugliosi and others, 2014). The last meltwater outflow to the south across the moraine was through a channel at about $1,220 \mathrm{ft}$ altitude (fig. 8). The ice tongue associated with this moraine occupied the West Branch Cayuga Inlet Valley and was a deflection of ice from the major tongue in the Cayuga Inlet Valley. A later margin of the ice tongue within this valley is immediately east of Newfield hamlet at the junction with the Cayuga Inlet Valley.

Two other inferred Valley Heads moraine positions are at the ends of the Fish Kill and Connecticut Hill Road Valleys, both within the Fish Kill drainage, which is part of the Enfield Creek drainage (figs. 3 and 8). Ice from the north over upland areas and from the northeast from the Cayuga Inlet trough halted at these positions.

The Connecticut Hill Road Valley ice position was noted in Denny and Lyford (1963) and is marked by a relatively flat, terraced surface between about 1,575 and 1,600 ft at the head of this narrow valley (fig. 8). This small headwater area is likely mostly filled with till but was leveled by meltwater drainage from the north around the base of Connecticut Hill and from the ice in this valley; the drainage was shunted southward through a narrow notch (a col) down the presentday Carter Creek drainage area. This meltwater discharged into the ice-free Pony Hollow Creek Valley about $3 \mathrm{mi}$ south (see Bugliosi and others, 2014).

The ice margin inferred just north of section $B-B^{\prime}$ (fig. 8) represents the termination of an ice tongue at the southern end of the Fish Kill Valley at its junction with the West Branch Cayuga Inlet Valley. The Fish Kill Valley ice was probably blocked by a thicker ice tongue that occupied the West Branch Cayuga Inlet Valley. The accumulation of sediment, including kame moraine and other ice-contact deposits, in the Fish Kill Valley to the north indicates that meltwater and sediment was more plentiful in Fish Kill Valley than in the West Branch Cayuga Inlet Valley. Southward drainage around stagnant ice toward the Pony Hollow Creek Valley can be inferred because the kame moraine at the valley junction is higher than the lowest outlet at the Pony Hollow kame moraine and because the deposits are connected by nearly continuous valley-side kame deposits and possibly in the valley bottom by small-scale crevasse-fill deposits that are interspersed with postglacial swamp deposits at land surface (fig. 8).

The form of the kame moraine immediately south of the ice position in the Fish Kill Valley is a terrace with a somewhat uneven top that spans the valley, except where it has been breached by a former meltwater channel. The present-day divide between the Fish Kill and West Branch Cayuga Inlet drainage areas (at about 1,175 to $1,180 \mathrm{ft}$ ) crosses this channel. South of the terrace, uneven kame deposits cover most of the adjacent West Branch Cayuga Inlet Valley, which likely represents sediment deposition on stagnant ice with subsequent melt out. The terrace grades northward into kame terraces along the valley walls and a low swampy flat where stagnant ice remained during deposition of the kame terraces.

\section{Deglaciation from the Valley Heads Ice Margin}

The mode of deglaciation from the Valley Heads position in much of the Newfield area appears to have been thinning of ice to the point of stagnation, with downwasting of remnant ice blocks and limited sediment infill. For example, remnant ice had to be present in the area behind the Pony Hollow kame moraine in the West Branch Cayuga Inlet Valley; otherwise, a uniform flat-topped delta would have prograded southward from the Fish Kill ice-margin position (rather than the actual irregular topography of knolls and swales caused by melting of buried ice after deposition of the sand and gravel) and the wetland midway between sections $A-A^{\prime}$ and $B-B^{\prime}$ (fig. 8) would not be interrupted by the many low gravel ridges that accumulated in crevasses within a large stagnant ice block.

Ice-contact deposits and till are the most abundant glacial deposits in the valley fill of the study area; lacustrine deposits are present at land surface in the lower West Branch Cayuga Inlet Valley and at intermediate depth in West Branch and Fish Kill Valleys; outwash deposits are largely absent (fig. 8). Some deposits described in drillers' logs as hard pan may be either lacustrine deposits or till made up of reworked lacustrine sediments. Till is the dominant surficial glacial deposit in the highaltitude Connecticut Hill Road Valley and in the northernmost part of the Fish Kill Valley.

Ice retreat out of the study area toward the main tongue in the Cayuga Inlet Valley was interrupted by pauses, as indicated by at least one ice-margin position at an altitude of about $1,100 \mathrm{ft}$, east of Newfield hamlet. It forms a morainic loop or lateral moraine at the junction of the West Branch Cayuga Inlet Valley with the Cayuga Inlet Valley. Within the loop, the soil survey data indicate predominantly fine-grained lacustrine deposits with minor till and sand and gravel (Neeley, 1961). The lacustrine deposits may be draped over coarser stratified material as there is a delta-form feature that may represent early sediment accumulation from the West Branch Cayuga Inlet adjacent to ice in the Cayuga Inlet Valley. A second possible ice position (not shown) is in the lower Fish Kill Valley just north of the junction with the Connecticut Hill Road Valley. It is marked by a narrowing of the valley floor, with till on the southeastern side and ice-contact deposits on the northwestern side (fig. 8).

As the study area became ice free, more than 13,000 years ago (Miller and Karig, 2010, table 1), erosion of unvegetated glacial deposits began, principally by water action (alluvium, alluvial fans) and by gravity-driven mass movement of till on steep, unstable slopes. Erosion continues to the present day, but at lower rates because of vegetative cover. Organic deposits (peat and muck) have accumulated in poorly drained areas (fig. 8). Alluvial fans form where a high-gradient 
tributary stream enters a low-gradient valley and drops its sediment load. Some large alluvial fans are adjacent to icecontact deposits and it is likely that tributary sediment inflows have continuously contributed first to the ice-contact deposits and then to the alluvial fans after the ice melted.

\section{Stratified-Drift Aquifers}

Stratified-drift aquifers in the study area are primarily composed of ice-contact deposits, although the origin of some of the deep deposits is uncertain. At land surface, they take the form of kame moraines and kames. These deposits can vary greatly in grain size and degree of sorting over short distances; water-resource potential is also highly variable. Both unconfined and confined aquifers are present in the valleys (fig. 3); the unconfined aquifer is limited in areal extent and saturated thickness and is rarely used (primarily by old wells), whereas the confined aquifer is more widespread and is used for both municipal and domestic supply.

\section{Unconfined Aquifer}

The unconfined aquifer encompasses most of the icecontact deposits and alluvial fans mapped in the upper reaches of the West Branch Cayuga Inlet and Fish Kill Valleys (figs. 6 through 9). Two small wetland areas behind the kame moraines are excluded because they are likely underlain by fine-grained lacustrine deposits. This aquifer is absent in most of the Connecticut Hill Road Valley and in the lower reaches of the West Branch Cayuga Inlet and Fish Kill Valleys. Waterresource potential is limited in this aquifer in part because streamflows are small in these high-altitude valleys, limiting the potential of pumped wells to induce infiltration of stream water into the aquifer.

The unconfined aquifer is tapped by few domestic wells. The areas with the greatest potential for water resources are in extensive ice-contact deposits (kame moraines and kames) in the valleys where permeable saturated sediments are likely thickest. Some kame moraine deposits may be partially confined by thin layers of till or lacustrine sediments. The highest estimated well yield from this aquifer is about 100 gallons per minute (gal/min) at well TM 275, at the Pony Hollow kame moraine. The extent and saturated thickness of the unconfined aquifer at the Fish Kill kame moraine was not determined. If the lacustrine deposits in hydrogeologic section $B-B^{\prime}$ (fig. $7 B$ at back of report) are absent on the northwestern (Fish Kill Valley) side, there may be a substantial thickness of unconfined, saturated sand and gravel. Elsewhere, there is only modest resource potential in this aquifer because the shallow gravels (especially at alluvial fans) are commonly described as silty, dirty, or hardpan (likely debris flow deposits) with generally thin saturated thicknesses. Where poorly sorted alluvial fan deposits are underlain by ice-contact (kame) sand and gravel, more favorable water resources are possible. For example, well TM 2829 (fig.4; U.S. Geological Survey, 2019) is on an alluvial fan in which the upper $15 \mathrm{ft}$ is described as hardpan (interpreted as debris flow deposits), which at least locally semiconfine $7 \mathrm{ft}$ of unsaturated sand and gravel and $33 \mathrm{ft}$ of saturated sand and gravel. The well is completed with open-ended casing and has a reported yield of $15 \mathrm{gal} / \mathrm{min}$. Several other wells along the valley walls may also tap this aquifer, but well logs for those wells do not exist.

\section{Confined Aquifer}

Confined aquifers are inferred to exist in most valleys of the study area (figs. 3 and $7 A-F$; fig. 7 at back of report). These aquifers consist of a single basal sand-and-gravel unit that extends over much of each valley (fig. 7A, $B, D$, and $F$ ), but two confined units are indicated in the lowest reach of the West Branch Cayuga Inlet (fig. 7C) and at the head of the Connecticut Hill Valley (fig. $7 E$ ). Along the western side of Fish Kill Valley, till that may have slumped from the hillside may locally confine shallow ice-contact (kame) deposits (fig. 7D). Well data indicate that till is the confining unit in the lower Fish Kill Valley, lower West Branch Cayuga Inlet Valley, and most of the Connecticut Hill Road Valley. In the main valleys, till may be reworked lacustrine deposits. Lacustrine deposits are probably the primary confining units immediately north of the Pony Hollow and Fish Kill kame moraines.

Reported confined aquifer thickness ranges from a few feet to at least $42 \mathrm{ft}$ near well TM1205. Permeability is locally variable but appears greatest in the largest-area, lowest valley reaches where meltwater was more abundant (fig. $7 B$ ) and less so in the highest altitude valleys where meltwater was limited (fig. $7 E$ ). The wells along section $E-E^{\prime}$ penetrated two silty sand and gravel units and were completed in shallow bedrock.

The highest-reported well yields from this aquifer are from the town production wells west of Newfield, which use pumps rated at $200 \mathrm{gal} / \mathrm{min}$ (Newfield Town Planning Board, 2010). Domestic wells in the valleys commonly tap this aquifer, especially in the Fish Kill Valley as indicated in sections $D-D^{\prime}$ and $F-F^{\prime}$ (fig. $7 D$ and $F$ ), and particularly at new residential housing in the area northeast of section $F-F^{\prime}$.

Confined aquifers with high water-resource potential are most extensive in valley-bottom areas at or behind kame moraines or kames, such as the Pony Hollow and Fish Kill kame moraines and the wetland areas north of them. Potential aquifer yield in these and other valley areas were not determined. For example, the depth to bedrock and thickness of the confined aquifer across most of hydrogeologic section $D-D^{\prime}$ (fig. $7 D$ ) is unknown and may be substantial; domestic wells in this section are drilled only into the upper part of the confined aquifer because sufficient yield has already been obtained, so no hydrogeologic data for depths below the upper part of the confined aquifer are available.

A confined aquifer outside of a valley setting occurs east of the junction of Fish Kill Valley with the Enfield Creek Valley at the northeastern corner of the study area (fig. $7 F$ ). Sand and gravel confined by till is draped across the convex 



04232890 U.S. Geological Survey site identification number

(0.222) Measurement number and associated discharge, in million gallons per day

Figure 9. Map showing locations of seepage synoptic surface water sites in Newfield, Tompkins County, New York. See also Fisher and Keto (2021a). 
lower northern slope of Protts Hill (fig. 3). The sand-andgravel deposit is thin but at least partly saturated at the high point in hydrogeologic section $F-F^{\prime}$, but wells at that location are completed in bedrock because of limited water storage in the sand and gravel. Water levels in the bedrock wells indicate a downward gradient, from the sand and gravel deposit, but confinement by the till layer likely limits recharge in this area. Domestic wells at lower altitude closer to the Fish Kill tap the confined sand and gravel aquifer. The thicknesses of the sand and gravel deposits and the aquifer are inferred to thicken westward toward the Fish Kill, but wells in that area do not reach bedrock, so aquifer thickness is unknown.

The Connecticut Hill Road Valley is the highest altitude valley in the study area and is inferred to have a modest confined aquifer (fig. 8). Apart from alluvium, there is little or no other stratified drift on the valley bottom except in the lowest reach of the valley. This indicates that recharge to confined aquifer material is small. The few well logs available for this valley indicate some stratified material within or beneath the till (fig. $7 E$ ), but it is likely suitable only for domestic supply.

No confined aquifer is delineated in the West Branch Cayuga Inlet Valley at its junction with the Cayuga Inlet Valley. There may be stratified material in this area, but it likely incorporates deformed till and lacustrine sediments deposited close to ice. Also, the West Branch Cayuga Inlet Valley is a hanging valley such that groundwater may drain into the Cayuga Inlet Valley, leaving limited saturated thickness in any coarse stratified aquifer material near the valley wall.

\section{Groundwater Recharge}

Groundwater is primarily recharged by the infiltration of precipitation onto the land surface either by rain or snowmelt. Understanding groundwater recharge is essential to determining the long-term availability of the groundwater in a specific aquifer system as well as determining a groundwater withdrawal budget. Aquifer recharge occurs mostly at two periods during the year, March through April, and mid-October through mid-December. The reason for this is that vegetation is dormant during these times, which decreases evapotranspiration, allowing more aquifer recharge and storage. During the growing season from May through mid-October, the average rate of evapotranspiration is typically greater than the rate of precipitation, causing a net decrease in water levels and storage.

Recharge into unconfined aquifers can be more easily estimated than recharge into confined aquifers because the material overlying unconfined aquifers is much more permeable, allowing water to infiltrate through the overlying material and into the aquifer. Recharge into confined aquifers is more difficult to estimate and is typically much more limited compared with unconfined aquifers because the confining layers of overlying material are much less permeable (Lyford and Cohen, 1988; Kontis and others, 2004). Changes in water levels in a confined aquifer generally have a much greater lag time in reaction to precipitation events because the aquifers are less exposed to the atmosphere.

Other sources of recharge include unchannelized runoff from hills that border surficial aquifers and seepage losses from streams that flow across these aquifers, especially where streams cross alluvial fans (Randall, 1978). Seepage measurements were performed on August 31 and September 1, 2016, at 11 locations along the West Branch Cayuga Inlet and 7 locations along the Fish Kill (fig. 9; table 1) to determine where these streams were losing surface water to the aquifer. Every location where seepage was measured showed streamflow gains as the water flowed downstream except for a stretch along the West Branch Cayuga Inlet between sites 422104076364901 and 422138076355701 (fig. 9). Four production wells (TM1205, TM1549, TM1620, and TM1633; fig. 4) near the losing reach of the West Branch Cayuga Inlet may account for the streamflow loss at the two stretches if there is a sufficient magnitude of water being withdrawn from the surficial aquifer.

\section{Groundwater Discharge}

Groundwater is naturally discharged to the West Branch Cayuga Inlet and Fish Kill as well as to evapotranspiration chiefly from wetlands overlying the aquifer. Groundwater is also withdrawn by domestic and production wells. Groundwater discharge is generally continual throughout the year, but evapotranspiration is lower when the vegetation is dormant from mid-October through April; during these months, aquifer recharge is greater than discharge and the amount of water stored in aquifers increases. During the growing season, from about May through mid-October, the rate of discharge is greater than the rate of recharge, which is reflected by a decrease in groundwater levels that indicate a decrease in aquifer storage.

The total annual withdrawal from groundwater for the West Branch Cayuga Inlet and Fish Kill aquifer system was 57.9 million gallons (Mgal; table 2). The majority of known groundwater withdrawals from stratified-drift aquifers within the study area are from the confined aquifer. The largest single withdrawal from the confined aquifer was from Town of Newfield production wells, which pumped 49.4 Mgal in 2012. Data on groundwater withdrawals (table 2) were obtained from the Town of Newfield Water and Sewer Division for the 2012 reporting year. Withdrawals for domestic and agricultural wells that tap into the stratified-drift (sand and gravel) aquifers were estimated by doing a visual count of houses, businesses, and farms over the aquifer boundaries using orthoimages and tax parcels. The number of wells within the aquifer boundaries that were known to tap into bedrock were subtracted from this estimation, resulting in a count of 135 wells. The visual count was then multiplied by 2.3 , the average number of persons per household in Tompkins County (U.S. Census Bureau, 2012), resulting in an estimated 310 people that relied on water 
Table 1. Discharge measurements made on selected streams in the West Branch Cayuga Inlet and Fish Kill Valleys, Newfield, Tompkins County, New York.

[USGS, U.S. Geological Survey; Mgal/d, million gallons per day; ft³/s, cubic foot per second; W, west; Trib., tributary; Br, branch; St Rt, State route; Rd, road; Co, county; CR, county road; NY, New York]

\begin{tabular}{lllll}
\hline $\begin{array}{c}\text { USGS station } \\
\text { identification } \\
\text { number }\end{array}$ & \multicolumn{1}{c}{ Station name } & \multicolumn{1}{c}{$\begin{array}{c}\text { Date } \\
\text { measured }\end{array}$} & $\begin{array}{c}\text { Discharge } \\
\text { (Mgal/d) }\end{array}$ & $\begin{array}{c}\text { Discharge } \\
\text { (ft } 3 / \mathbf{s} \text { ) }\end{array}$ \\
\hline 422005076375201 & W Branch Cayuga Inlet at St Rt 13, Newfield, NY & $8 / 31 / 2016$ & Dry & Dry \\
422035076372901 & W Branch Cayuga Inlet Trib. at St Rt 13, Newfield, NY & $8 / 31 / 2016$ & Dry & Dry \\
422047076373301 & W Branch Cayuga Inlet at Test Rd, Newfield, NY & $8 / 31 / 2016$ & Wetland & Wetland \\
422052076374301 & W Branch Cayuga Trib. at Co Road 133A, Newfield, NY & $8 / 31 / 2016$ & Dry & Dry \\
422132076372601 & W Br Cayuga Inlet Trib. near Co Rd 133, Newfield, NY & $8 / 31 / 2016$ & Dry & Dry \\
422104076364901 & W Br Cayuga Inlet near St Rt 13, Newfield, NY & $8 / 31 / 2016$ & 0.121 & 0.224 \\
422110076364001 & W Br Cayuga Inlet Trib. near St Rt 13, Newfield, NY & $8 / 31 / 2016$ & Dry & Dry \\
422138076355701 & W Br Cayuga Inlet at County Road 133, Newfield, NY & $8 / 31 / 2016$ & 0.101 & 0.187 \\
04232890 & West Branch Trib. below Main St at Newfield, NY & $8 / 31 / 2016$ & 0.026 & 0.048 \\
422139076355501 & W Br Cayuga Inlet 400 ft below CR 133, Newfield, NY & $8 / 31 / 2016$ & 0.122 & 0.226 \\
422139076355301 & W Br Cayuga Inlet 500 ft below CR 133, Newfield, NY & $8 / 31 / 2016$ & 0.164 & 0.305 \\
422240076364501 & Fish Kill at Horton Road, Newfield, NY & $9 / 1 / 2016$ & 0.093 & 0.173 \\
0423315020 & Fish Kill Trib. Near Newfield, NY & $9 / 1 / 2016$ & 0.017 & 0.032 \\
0423315025 & Fish Kill at County Road 134, Newfield, NY & $9 / 1 / 2016$ & 0.133 & 0.247 \\
0423315035 & Fish Kill Trib. at Fishkill Road, Newfield, NY & $9 / 1 / 2016$ & 0.010 & 0.185 \\
0423315040 & Fish Kill at Douglas Road, Newfield, NY & $9 / 1 / 2016$ & 0.222 & 0.412 \\
422336076355301 & Fish Kill Trib. at Stonehouse Road, Newfield, NY & $9 / 1 / 2016$ & Dry & Dry \\
0423315042 & Fish Kill near Robert H. Treman State Park, NY & $9 / 1 / 2016$ & 0.262 & 0.486 \\
\hline
\end{tabular}

Table 2. Groundwater withdrawals in the West Branch Cayuga Inlet and Fish Kill Valleys in Newfield, New York, in 2012.

[Groundwater withdrawals were reported by the Town of Newfield and were estimated for users that reside over the stratified-drift (sand and gravel) aquifers. -, no data]

\begin{tabular}{|c|c|c|c|}
\hline Users & $\begin{array}{c}\text { Private homes over } \\
\text { the stratified-drift } \\
\text { aquifers }\end{array}$ & $\begin{array}{l}\text { Town of } \\
\text { Newfield } \\
\text { production } \\
\text { wells }^{4}\end{array}$ & Total \\
\hline Estimated number of wells that tap the stratified-drift (sand and gravel) aquifers 1 & 135 & - & - \\
\hline Average people per household 2 & 2.3 & - & - \\
\hline Estimated number of people using water from stratified-drift (sand and gravel) aquifers & 310 & - & - \\
\hline Estimated daily withdrawal, in gallons & 23,300 & - & - \\
\hline $\begin{array}{l}\text { Estimated annual withdrawal from stratified-drift (sand and gravel) aquifers, in million } \\
\text { gallons per day }\end{array}$ & $8,500,000$ & $49,400,000$ & $57,900,000$ \\
\hline
\end{tabular}

\footnotetext{
${ }^{1}$ The estimated number of wells that tap the stratified-drift (sand and gravel) aquifers were determined by a visual count of homes, farms, and businesses over the aquifer area on orthoimage maps. Then the number of wells within the aquifer area that are known to tap bedrock was subtracted from the total number of wells.

${ }^{2}$ Data are from U.S. Census Bureau (2012).

${ }^{3}$ Data are from Hutson and others (2000).

${ }^{4}$ Total estimated withdrawal for 2012 provided by the Town of Newfield.
} 
withdrawn from private wells (table 2). The estimated annual withdrawal from wells not on public supply was 23,300 gallons per day (gal/d) and 8.5 million gallons per year from the stratified-drift (sand and gravel) aquifers. This total was based on an estimate using the average water use of $75 \mathrm{gal} / \mathrm{d}$ per person for self-supplied water systems in New York (Maupin and others, 2014). This average water use was then multiplied by the estimated 310 people that relied on water withdrawn from private wells from the aquifer to calculate an estimated $23,300 \mathrm{gal} / \mathrm{d}$, multiplied by 365 days a year for a total annual withdrawal of $8.5 \mathrm{Mgal}$.

\section{Quality of Surface Water and Groundwater in the Stratified-Drift Aquifer in Newfield}

One set of surface-water samples was collected during base-flow conditions at the West Branch Cayuga Inlet at Newfield, N.Y. (04232900) and Fish Kill near mouth (422353076353201) USGS streamgages (fig. 3). Base-flow conditions exist when there is sustained flow in a stream without direct runoff from other sources, including natural and human-induced stream flows. Natural base flow is sustained largely by groundwater discharges. Both samples were collected on November 19, 2012. The two surface-water samples were analyzed for physical parameters, common ions, and nutrients at the NWQL.

Groundwater samples were collected at two separate times over a period of a few months. Five wells were sampled in 2012, and six USGS monitoring wells were sampled in 2015. All groundwater samples were analyzed for physiochemical parameters, common ions, nutrients, radiochemical activities, and trace elements at the NWQL. Dissolved atmospheric gases were analyzed by the Reston Groundwater Dating Laboratory using the methods outlined in Busenberg and Plummer $(2000,2008)$. The stratified-drift aquifer studies outlined in Miller and Karig (2010), Miller and Bugliosi (2013), Bugliosi and others (2014), Miller (2015), and Fisher and others (2019) were for aquifers in Tompkins County and can serve as a comparison of water-quality results for this study.

\section{Surface Water}

Surface-water-quality samples were collected from West Branch Cayuga Inlet and Fish Kill during base-flow conditions to obtain a baseline of the water quality overlying the aquifer. Results for chemical analyses of surface water samples are presented in this section (table 3 ).

\section{Physiochemical Properties}

Water samples collected from the West Branch Cayuga Inlet and Fish Kill USGS sampling locations had alkaline $\mathrm{pH}$ values of 8.3 and 8.4 , respectively (table 3 ). The samples had specific conductance concentrations of 478 and 430 microsiemens per centimeter at 25 degrees Celsius $\left(\mu \mathrm{S} / \mathrm{cm}\right.$ at $\left.25^{\circ} \mathrm{C}\right)$, respectively, and dissolved oxygen concentrations of 10.2 and 10.4 milligrams per liter $(\mathrm{mg} / \mathrm{L})$, respectively.

\section{Common lons and Nutrients}

Common ion concentrations at the two USGS streamgages were similar (table 3). Concentrations of hardness, calcium, alkalinity, bicarbonate, bromide, fluoride, sulfate, and dissolved solids in the Fish Kill were within 9 percent or less of those in the West Branch Cayuga Inlet. The constituents with the greatest difference in concentration between the two stream sites were potassium, sodium, and chloride. The samples from the West Branch Cayuga Inlet sampling location had higher concentrations of all three constituents than the samples from the Fisk Kill sampling location, which is likely a result of human activity. The higher concentrations of sodium and chloride at the West Branch Cayuga Inlet may be due to the geographic location of the inlet. The site is within Newfield hamlet and is close to local roads and State Route 13 where road salt application in the winter may increase sodium and chloride concentrations. By contrast, the Fish Kill sampling location is in the Robert Treman State Park next to a local road that is open on a seasonal basis and the surrounding area is mostly forested with very sparse housing. None of the common ions exceeded existing drinking water standards at either site.

The majority of nutrient concentrations were below detection levels (table 3; Fishman, 1993). The highest nutrient concentration $(0.4 \mathrm{mg} / \mathrm{L}$ as $\mathrm{N})$ was for nitrate plus nitrite in the West Branch Cayuga Inlet site, well below the U.S. Environmental Protection Agency (EPA) drinking-water standard of $10 \mathrm{mg} / \mathrm{L}$ (U.S. Environmental Protection Agency, 2012). Total phosphorus was detected at $0.01 \mathrm{mg} / \mathrm{L}$ for both sites (table 3).

\section{Groundwater}

Groundwater samples were taken to gain a better understanding of the water quality of the stratified-drift aquifers in the study area. Samples were collected in fall 2012 from the Newfield production wells and two domestic bedrock wells. An additional set of samples were collected from the seven USGS monitoring wells on July 30, 2015. All samples were analyzed for physiochemical parameters, common ions, nutrients, radiochemical activities, trace elements, and dissolved atmospheric gases. 
Table 3. Physical properties and concentrations of common ions and nutrients in surface-water samples from West Branch Cayuga Inlet and Fish Kill, Newfield, Tompkins County, New York.

[Locations of sampling sites are shown in figure 3. Parm code, U.S. Geological Survey National Water Information System parameter $\mathrm{code}^{\circ} \mathrm{CaCO}_{3}$, calcium carbonate; $\mathrm{mg} / \mathrm{L}$, milligram per liter; $\mu \mathrm{S} / \mathrm{cm}$ at $25^{\circ} \mathrm{C}$, microsiemens per centimeter at 25 degrees Celsius; <, less than]

\begin{tabular}{|c|c|c|c|}
\hline \multirow[b]{2}{*}{ Constituent } & \multirow[b]{2}{*}{$\begin{array}{l}\text { NWIS param- } \\
\text { eter code }\end{array}$} & \multicolumn{2}{|c|}{ Concentrations of constituents } \\
\hline & & $\begin{array}{c}\text { West Branch Cayuga Inlet at } \\
\text { Newfield, NY } \\
04232900 \\
11 / 19 / 2012 \\
\end{array}$ & $\begin{array}{c}\text { Fish Kill } \\
\text { near mouth } \\
422353076353201 \\
\text { 11/19/2012 } \\
\end{array}$ \\
\hline \multicolumn{4}{|c|}{ Physiochemical properties } \\
\hline $\mathrm{pH}$ (lab), in pH units & 403 & 8.3 & 8.4 \\
\hline Specific conductance (lab), in $\mu \mathrm{S} / \mathrm{cm}$ at $25^{\circ} \mathrm{C}$ & 90095 & 478 & 430 \\
\hline Dissolved oxygen (field), in mg/L & 300 & 10.2 & 10.4 \\
\hline \multicolumn{4}{|c|}{ Common inorganic ions } \\
\hline Hardness, filtered, as $\mathrm{CaCO}_{3}$, in $\mathrm{mg} / \mathrm{L}$ & 900 & 199 & 194 \\
\hline Calcium, filtered, in $\mathrm{mg} / \mathrm{L}$ & 915 & 59.8 & 59.6 \\
\hline Magnesium, filtered, in $\mathrm{mg} / \mathrm{L}$ & 925 & 12.1 & 10.9 \\
\hline Potassium, filtered, in mg/L & 935 & 1.49 & 0.1 \\
\hline Sodium, filtered, in mg/L & 930 & 26.1 & 18.7 \\
\hline Alkalinity, filtered, as $\mathrm{CaCO}_{3}$, in $\mathrm{mg} / \mathrm{L}$ & 29801 & 165 & 168 \\
\hline Bicarbonate, filtered, as $\mathrm{CaCO}_{3}$, in $\mathrm{mg} / \mathrm{L}$ & 453 & 197 & 199 \\
\hline Bromide, filtered, in $\mathrm{mg} / \mathrm{L}$ & 71870 & 0.02 & 0.02 \\
\hline Chloride, filtered, in $\mathrm{mg} / \mathrm{L}$ & 940 & 43 & 27.8 \\
\hline Fluoride, filtered, in $\mathrm{mg} / \mathrm{L}$ & 950 & 0.05 & 0.05 \\
\hline Silica, filtered, in mg/L & 955 & 4.37 & 5.3 \\
\hline Sulfate, filtered, in $\mathrm{mg} / \mathrm{L}$ & 945 & 17.4 & 17.4 \\
\hline Dissolved solids, dried at $180^{\circ} \mathrm{C}$, in $\mathrm{mg} / \mathrm{L}$ & 70300 & 268 & 246 \\
\hline \multicolumn{4}{|c|}{ Nutrients } \\
\hline Ammonia $\left(\mathrm{NH}_{3}+\mathrm{NH}_{4}^{+}\right)$, as N, filtered, in $\mathrm{mg} / \mathrm{L}$ & 608 & $<0.010$ & $<0.003$ \\
\hline Nitrate plus nitrite, as $\mathrm{N}$, filtered, in $\mathrm{mg} / \mathrm{L}$ & 631 & 0.4 & 0.18 \\
\hline Nitrite, as N, filtered, in $\mathrm{mg} / \mathrm{L}$ & 613 & 0.001 & $<0.001$ \\
\hline Orthophosphate, as $\mathrm{P}$, filtered, in $\mathrm{mg} / \mathrm{L}$ & 671 & $<0.004$ & $<0.004$ \\
\hline Phosphorus, filtered, in $\mathrm{mg} / \mathrm{L}$ & 666 & $<0.003$ & $<0.003$ \\
\hline Phosphorus, unfiltered, in $\mathrm{mg} / \mathrm{L}$ & 665 & 0.01 & 0.01 \\
\hline
\end{tabular}

\section{Physiochemical Properties}

Dissolved oxygen concentrations ranged from 0.1 to $0.9 \mathrm{mg} / \mathrm{L}$ at all wells except for well TM 923 , which had a value of $7.7 \mathrm{mg} / \mathrm{L}$. This well was a dual-completion well with well TM 418 wherein the shallow well TM 923 was separated from the deep well TM 418 by installing and finishing a well casing into a higher aquifer zone and sealing it off from the deeper well using bentonite clay on top of pea gravel. Wells TM 418 and TM 923 are artesian wells, meaning they are under positive pressure from a confining unit above. The shallower of the two wells, TM 923, has higher dissolved oxygen concentrations likely because it may receive local recharge from the hill to the west, which never reaches the deeper aquifer tapped by well TM 418.

The $\mathrm{pH}$ values of all groundwater samples were alkaline, ranging from 7.1 to 9.0 (median value of 8.1). Of the 11 samples taken, 3 exceeded the accepted secondary maximum containment level (SMCL) for $\mathrm{pH}$ range of 6.5 to 8.5 set by the EPA (U.S. Environmental Protection Agency, 2012). Well TM2829 exceeded the limit with a value of 9.0; well TM1205, with a value of 8.8; and well TM 419, with a value of 8.6. Specific conductance concentrations ranged from $287 \mu \mathrm{S} / \mathrm{cm}$ at $25^{\circ} \mathrm{C}$ at well TM418 to $1,670 \mu \mathrm{S} / \mathrm{cm}$ at $25{ }^{\circ} \mathrm{C}$ at well TM1061. 


\section{Common lons and Nutrients}

Most of the common ion concentrations were similar at each well sampled with the exception of those for sodium and chloride at wells that were finished in or just above bedrock in the middle of valleys, which is reflected in the difference in specific conductance (table 3.1). Of the 11 samples taken, 5 exceeded the EPA advisory level for sodium intake in drinking water for those on a salt-restricted diet of $20 \mathrm{mg} / \mathrm{L}$ (U.S. Environmental Protection Agency, 2003). Well TM2829 had a concentration of $105 \mathrm{mg} / \mathrm{L}$, and well TM1061 had a concentration of $206 \mathrm{mg} / \mathrm{L}$. The concentration of chloride at well TM2829 was just below the EPA SMCL of $250 \mathrm{mg} / \mathrm{L}$, and the $421-\mathrm{mg} / \mathrm{L}$ concentration at well TM1061 was well above the SMCL (table 3.1). Chloride concentrations above $250 \mathrm{mg} / \mathrm{L}$ have aesthetic effects on the water quality, such as odor and taste; chlorides tend to give the water a salty taste (U.S. Environmental Protection Agency, 2012). At wells TM2829 and TM1061, high values of specific conductance and sodium and chloride concentrations are likely attributed to applications of road salt. Sources of chloride can be assessed by looking at chloride-to-bromide mass ratios (Williams and Kappel, 2015). Road salt sources of chloride typically have high chloride-to-bromide mass ratios (where chloride is elevated but bromide is not). The chloride-to-bromide ratio for well TM2829 was 11,950, which is likely more indicative of road salt than a natural source of chloride. The chlorideto-bromide mass ratios for wells TM1061 and TM1205 were 110 and 117 , respectively, which are more likely indicative of a natural source.

The majority of results for nutrient concentrations fell below the detection limit for each constituent (table 3.1). Although there were detections for each constituent at several wells, no constituents came close to or exceeded any drinkingwater standard. The maximum nitrate concentration was $1.61 \mathrm{mg} / \mathrm{L}$ as nitrogen $(\mathrm{mg} / \mathrm{L}$ as N) at well TM1062, and the maximum ammonia concentration was $0.349 \mathrm{mg} / \mathrm{L}$ as $\mathrm{N}$ at well TM1061.

\section{Radiochemical Activities}

The gross-alpha radioactivity, unfiltered, value was 2.4 picocuries per liter $(\mathrm{pCi} / \mathrm{L})$. The gross-beta radioactivity, unfiltered, value was $\mathrm{R} 0.80 \mathrm{pCi} / \mathrm{L}$. The " $\mathrm{R}$ " in the sample result in this case means that the result is below the samplespecific critical level, which is the smallest measured concentration that is statistically different from the instrument background or analytical blank. It serves as the detection threshold for deciding whether the radionuclide is present in a sample and is calculated from measurements obtained using the same analytical parameter values that were used during the analysis of the sample (McCurdy and others, 2008).

\section{Dissolved Atmospheric Gases and Chlorofluorocarbon-Derived Groundwater Age}

Dissolved atmospheric gases were collected at wells TM1205, TM1620, TM2829, TM1061, TM1062, TM 419, TM 418, and TM 277. Methane concentrations ranged from 0 to $8.01 \mathrm{mg} / \mathrm{L}$, with a median value of $1.73 \mathrm{mg} / \mathrm{L}$. Dissolved nitrogen gas concentrations ranged from 19.9 to $25.7 \mathrm{mg} / \mathrm{L}$, with a median of $23.1 \mathrm{mg} / \mathrm{L}$. Argon concentrations ranged from 0.70 to $0.80 \mathrm{mg} / \mathrm{L}$, with a median of $0.75 \mathrm{mg} / \mathrm{L}$. Carbon dioxide gas concentrations ranged from 0.34 to $16.6 \mathrm{mg} / \mathrm{L}$, with a median of $4.92 \mathrm{mg} / \mathrm{L}$. Methane accumulation in deep, wellconfined sand and gravel aquifers and underlying bedrock in valleys of the Newfield area (table 3.1) is consistent with findings on methane occurrence in south-central New York (Heisig and Scott, 2013).

Chlorofluorocarbons (CFCs) were collected at wells TM1620, TM 419, TM 418, and TM 277. Estimated groundwater ages ranged from 35 to 75 years, which is generally consistent with confined conditions. For well TM1620, which was finished in a confined sand and gravel aquifer, CFC results showed a range in groundwater age (time since recharge) dating from the early 1940s to the late 1950s. For well TM 419, finished in a confined sand and gravel aquifer, the CFC results showed a range in groundwater age dating from the mid-1950s to the late 1960s. Well TM 418 was also finished in a confined sand and gravel aquifer and ranged in age from the late 1940s to the early 1970s. Well TM 277 was finished in sand and gravel and ranged in age from the mid-1940s to the late 1960s. These CFC-derived results show that the groundwater flow system is predominantly young groundwater.

\section{Trace Elements}

With the exception of iron and manganese, trace element concentrations were either below laboratory reporting level or below EPA enforceable and nonenforceable drinking-water standards (table 3.2). Similar to reported specific conductance and common ion values, the wells that were finished in or just above bedrock tended to have higher concentrations of iron, manganese, and barium than wells that were not.

Although no samples exceeded the EPA maximum contaminant level (MCL) of $10 \mu \mathrm{g} / \mathrm{L}$ for arsenic, the concentrations of the samples from wells TM1061 and TM1205 were relatively high with values of 6.56 and $2.24 \mu \mathrm{g} / \mathrm{L}$ compared with the concentrations from other samples. Well TM1061 is the only true bedrock well in that it is confined and pulling water directly from bedrock, whereas well TM1205 may be finished just above bedrock and is confined; this conclusion seems to be supported by the fact that trace element water-quality results from well TM1205 align more with well TM1061 than with those from the other sand and gravel wells. The arsenic concentrations in wells TM1061 and TM1205 are many times higher than in the sand and gravel wells. This may not necessarily point to high arsenic values across the study 
area in confined bedrock aquifers but is a point worth noting. The potential health effects from long-term exposure from concentrations above the MCL for arsenic are skin damage, problems with circulatory systems, and possible increased risk of getting cancer (U.S. Environmental Protection Agency, 2012). No samples had concentrations that exceeded the EPA MCL for barium $(2,000 \mu \mathrm{g} / \mathrm{L})$; however, wells TM1205 and TM1061 had concentrations that approached this threshold with values of 1,350 and $1,330 \mu \mathrm{g} / \mathrm{L}$, respectively. These concentrations, as well as the arsenic concentrations from these two wells, may be attributed to the chemical makeup of the underlying Sonyea bedrock group. The potential health effect from long-term exposure from concentrations above the MCL for barium is an increase in blood pressure (U.S. Environmental Protection Agency, 2012).

Eight of 11 ( 73 percent) samples analyzed had iron concentrations that exceeded the EPA SMCL of $300 \mu \mathrm{g} / \mathrm{L}$. High concentrations of iron have noticeable effects in the water, such as rusty color, sediment, metallic taste, and reddish or orange staining (U.S. Environmental Protection Agency, 2012). Eight of 11 (73 percent) samples had manganese concentrations above the EPA SMCL of $50 \mu \mathrm{g} / \mathrm{L}$, but none of the samples exceeded the New York State Department of Health MCL of $300 \mu \mathrm{g} / \mathrm{L}$ for manganese (table 3.2). High values of manganese concentrations $(>50 \mu \mathrm{g} / \mathrm{L}$ ) have noticeable effects in the water, such as a black to brown color, black staining, and a bitter metallic taste (U.S. Environmental Protection Agency, 2012). Nearly every well sampled had high values of iron and manganese spatially distributed over the aquifer boundaries. The concentrations for iron and manganese had the most drinking water standard exceedances of all constituents; which is noteworthy because these constituents would likely require treatment in the event of future development of the aquifer on a production or domestic scale.

\section{Summary}

From 2011 to 2016, the U.S. Geological Survey, in cooperation with the Town of Newfield and the Tompkins County Planning Department, began a study of the stratified-drift aquifers in the West Branch Cayuga Inlet and Fish Kill Valleys in Newfield, Tompkins County, New York. The aquifers include both confined and unconfined aquifers. The confined aquifer is a sand and gravel layer overlying bedrock. The unconfined aquifer includes kame sand and gravel that was deposited by glacial meltwater during the last glacial recession and alluvial silt and sand and gravel that was deposited by streams since that time to the present day, including several alluvial fans deposited in the valleys by large tributaries.

The unconfined aquifers are primarily recharged by direct infiltration of precipitation on land surface, surface runoff from adjacent hillsides that makes its way into the aquifer from the edges of the valleys, groundwater flow from adjacent till and bedrock that also makes its way into the aquifer along the edges of the valleys, and seepage loss from streams overlying the aquifer. The confined aquifers are primarily recharged by precipitation that falls directly on the surficial confining unit, then slowly flows downward, particularly through parts of the confining units that contain sediments with some degree of permeability.

The groundwater can leave the aquifer through (1) domestic, municipal, commercial, and agricultural wells; (2) Fish Kill and West Branch Cayuga Inlet; and (3) evapotranspiration, particularly from wetlands overlying the surficial aquifer. Approximately 57.9 million gallons per year was withdrawn from the stratified-drift (sand and gravel) aquifers.

Groundwater samples were collected from 11 wells, and surface-water samples were collected from the Fish Kill and the West Branch Cayuga Inlet. Of the 11 wells sampled, 8 were finished in confined sand and gravel aquifers, 1 was finished in unconfined sand and gravel, and 2 were finished in shale bedrock. Water quality in the study area generally met drinking-water standards; however, a few physiochemical properties and chemical constituents, including $\mathrm{pH}$, chloride, iron, and manganese, exceeded human health standards and goals set by Federal and State regulatory agencies in nine wells.

\section{References Cited}

Bugliosi, E.F., Miller, T.S., and Reynolds, R.J., 2014, Hydrogeology and water quality of the stratified-drift aquifer in the Pony Hollow Creek Valley, Tompkins County, New York: U.S. Geological Survey Scientific Investigations Report 2014-5059, 23 p., accessed March 23, 2018, at https://doi.org/10.3133/sir20145059.

Busenberg, E., and Plummer, L.N., 2000, Dating young groundwater with sulfur hexafluoride-Natural and anthropogenic sources of sulfur hexafluoride: Water Resources Research, v. 36, no. 10, p. 3011-3030, accessed March 23, 2018, at https://doi.org/10.1029/2000WR900151.

Busenberg, E., and Plummer, L.N., 2008, Dating groundwater with trifluoromethyl sulfurpentafluoride (SF5CF3), sulfur hexafluoride (SF6), CF3Cl (CFC-13), and CF2Cl2 (CFC-12): Water Resources Research, v. 44, no. 2, W02431, 18 p., accessed March 23, 2018, at https://doi.org/10.1029/ 2007WR006150.

Cadwell, D.H., and Muller, E.H., 2004, New York glacial geology, U.S.A., in Ehlers, J., and Gibbard, P.L., eds., Quaternary glaciations-Extent and chronology, part II, North America: Developments in Quaternary Science, v. 2, pt. B, p. 201-205. [Also available at https://doi.org/10.1016/ S1571-0866(04)80197-0.] 
Denny, C.S., and Lyford, W.H., 1963, Surficial geology and soils of the Elmira-Williamsport region, New York and Pennsylvania: U.S. Geological Survey Professional Paper 379, 60 p., 6 pls. [Also available at https://doi.org/ 10.3133/pp379.]

Fairchild, H.L., 1932, New York moraines: Geological Society of America Bulletin, v. 43, no. 3, p. 627-662, https://doi.org/10.1130/GSAB-43-627.

Fisher, B.N., Heisig, P.M., and Kappel, W.M., 2019, Geohydrology and water quality of the unconsolidated aquifers in the Enfield Creek Valley, town of Enfield, Tompkins County, New York (ver. 1.1, May 2020): U.S. Geological Survey Scientific Investigations Report 2019-5136, 52 p., accessed May 26, 2020, at https://doi.org/10.3133/ $\operatorname{sir} 20195136$.

Fisher, B.N., and Keto, D.S., 2021a, Geospatial datasets for the geohydrology and water quality of the stratified-drift aquifers in West Branch Cayuga Inlet/Fish Kill aquifers in Newfield, Tompkins County, New York: U.S. Geological Survey data release, https://doi.org/10.5066/P94Y3E81.

Fisher, B.N., and Keto, D.S., 2021b, Horizontal-to-vertical spectral ratio and depth-to-bedrock for geohydrology and water quality of the stratified-drift aquifer in West Branch Cayuga Inlet and Fish Kill Valleys, Newfield, Tompkins County, New York, July 2011-November 2016: U.S. Geological Survey data release, https://doi.org/10.5066/ P9N6AZ4E.

Fishman, M.J., ed., 1993, v. 1993-125. Methods of analysis by the U.S. Geological Survey National Water Quality Laboratory-Determination of inorganic and organic constituents in water and fluvial sediments, U.S. Geological Survey Open-File Report, 217 p. [Also available at https://doi.org/10.3133/ofr93125.]

Fullerton, D.S., 1980, Preliminary correlation of post-Erie interstadial events $(16,000-10,000$ radiocarbon years before present), central and eastern Great Lakes region, and Hudson, Champlain, and St. Lawrence lowlands, United States and Canada: U.S. Geological Survey Professional Paper 1089, 52 p., 2 pls. [Also available at https://doi.org/ 10.3133/pp1089.]

Heisig, P.M., and Scott, T.-M., 2013, Occurrence of methane in groundwater of south-central New York State, 2012 - Systematic evaluation of a glaciated region by hydrogeologic setting: U.S. Geological Survey Scientific Investigations Report 2013-5190, 32 p., accessed March 23, 2018, at https://doi.org/10.3133/sir20135190.

Hutson, S.S., Barber, N.L., Kenny, J.F., Linsey, K.S., Lumia, D.S., and Maupin, M.A., 2004, Estimated use of water in the United States in 2000: U.S. Geological Survey Circular 1268, 46 p., accessed March 23, 2018, at https://doi.org/ $10.3133 / \operatorname{cir} 1268$.
Karig, D.E., 2015, Quaternary geology of the greater Sixmile Creek watershed: Cornell University technical report, 64 p., accessed May 26, 2020, at https://ecommons.cornell.edu/ handle/1813/40572.

Karrow, P.F., 1984, Quaternary stratigraphy and history, Great Lakes-St. Lawrence region, in Fulton, R.J., ed., Quaternary stratigraphy of Canada-A Canadian contribution to IGCP Project 24: Geological Survey of Canada Paper 84-10, p. 137-153. [Also available at https://doi.org/ 10.4095/119765.]

Kontis, A.L., Randall, A.D., and Mazzaferro, D.L., 2004, Regional hydrology and simulation of flow of stratifieddrift aquifers in the glaciated northeastern United States: U.S. Geological Survey Professional Paper 1415-C, 156 p., 3 pls., accessed June 2018 at https://doi.org/ 10.3133/pp1415C.

Lane, J.W., Jr., White, E.A., Steele, G.V., and Cannia, J.C., 2008, Estimation of bedrock depth using the horizontalto-vertical (HVSR) ambient-noise seismic method, in Symposium on the Application of Geophysics to Engineering and Environmental Problems, April 6-10, 2008, Philadelphia, Pennsylvania, proceedings: Denver, Colo., Environmental and Engineering Geophysical Society, 13 p. [Also available at https://doi.org/10.4133/1.2963289.]

Lawson, J.T., 1977, Surficial and engineering geology of the Cayuga Inlet Valley, Ithaca, New York: Cornell University master's thesis, $84 \mathrm{p}$.

Lyford, P.P., and Cohen, A.J., 1988, Estimation of water available for recharge to sand and gravel aquifers in the glaciated northeastern United States, in Randall, A.D., and Johnson, A.I., eds., Regional aquifer systems of the United States, northeast glacial aquifers: American Water Resources Association Monograph Series 11, p. 37-61.

Maupin, M.A., Kenny, J.F., Hutson, S.S., Lovelace, J.K., Barber, N.L., and Linsey, K.S., 2014, Estimated use of water in the United States in 2010: U.S. Geological Survey Circular 1405, 56 p., accessed June 5, 2018, at https://doi.org/10.3133/cir1405.

McCurdy, D.E., Garbarino, J.R., and Mullin, A.H., 2008, Interpreting and reporting radiological water-quality data: U.S. Geological Survey Techniques and Methods, book 5, chap. B6, 33 p. [Also available at https://doi.org/ $10.3133 / \mathrm{tm} 5 \mathrm{~b} 6$.

Miller, T.S., 2000, Unconsolidated aquifers in Tompkins County, New York: U.S. Geological Survey WaterResources Investigations Report 2000-4211, 1 sheet. [Also available at https://doi.org/10.3133/wri004211.] 
Miller, T.S., 2015, Geohydrology and water quality of the stratified-drift aquifers in upper Buttermilk Creek and Danby Creek Valleys, town of Danby, Tompkins County, New York: U.S. Geological Survey Scientific Investigations Report 2015-5138, 66 p., accessed March 23, 2018, at https://doi.org/10.3133/sir20155138.

Miller, T.S., and Bugliosi, E.F., 2013, Geohydrology, water quality, and simulation of groundwater flow in the stratified-drift aquifer system in Virgil Creek and Dryden Lake Valleys, town of Dryden, Tompkins County, New York: U.S. Geological Survey Scientific Investigations Report 2013-5070, 104 p., accessed March 23, 2018, at https://doi.org/10.3133/sir20135070.

Miller, T.S., and Karig, D.E., 2010, Geohydrology of the stratified-drift aquifer system in the lower Sixmile Creek and Willseyville Creek trough, Tompkins County, New York: U.S. Geological Survey Scientific Investigations Report 2010-5230, 54 p., accessed March 23, 2018, at https://doi.org/10.3133/sir20105230.

Miller, T.S., and Pitman, L.M., 2012, Hydrogeology of the stratified-drift aquifers in the Cayuta Creek and Catatonk Creek Valleys in parts of Tompkins, Schuyler, Chemung, and Tioga Counties, New York: U.S. Geological Survey Scientific Investigations Report 2012-5127, 45 p., 3 pls., accessed May 23, 2020, at https://doi.org/10.3133/ sir20125127.

Muller, E.H., and Cadwell, D.H., 1986, Surficial geologic map of New York, Finger Lakes sheet: New York State Museum Geological Survey Map and Chart Series 40, scale 1:250,000.

Muller, E.H., and Calkin, P.E., 1993, Timing of Pleistocene glacial events in New York State: Canadian Journal of Earth Sciences, v. 30, no. 9, p. 1829-1845, accessed June 23, 2018, at https://doi.org/10.1139/e93-161.

Neeley, J.A., 1961, Soil survey of Tomkins County, New York: U.S. Department of Agriculture Series 1961, no. 25, 241 p. [Also available at https://www.nrcs.usda.gov/Internet/FSE_ MANUSCRIPTS/new_york/tompkinsNY1965/.]

Newfield Town Planning Board, 2010, Comprehensive plan inventory report of the town of Newfield: Newfield Town Planning Board, 38 p. [Also available at https://newfi eldny.org/planning/CPIR/InventoryReport.pdf.]

Randall, A.D., 1978, Infiltration from tributary streams in the Susquehanna River Basin: Journal of Research of the U.S. Geological Survey, v. 6, no. 3, p. 285-297. [Also available at https://pubs.er.usgs.gov/publication/70007426.]
Rantz, S.E., and others, 1982, Measurement of stage and discharge, v. 1 of Measurement and computation of streamflow: U.S. Geological Survey Water-Supply Paper 2175, 313 p., accessed March 23, 2018, at https://doi.org/ 10.3133/wsp2175.

Rickard, L.V., and Fisher, D.W., 1970, Geologic map of New York, Finger Lakes sheet: New York State Museum Geological Survey Map and Chart Series 15, 1:250,000.

U.S. Census Bureau, 2012, 2010 census of population and housing: U.S. Census Bureau data, accessed January 24, 2018, at https://www.census.gov/prod/cen2010/cph1-34.pdf.

U.S. Environmental Protection Agency, 2003, Drinking water advisory - Consumer acceptability advice and health effects analysis on sodium: U.S. Environmental Protection Agency 822-R-03-006, 1 p. [Also available at https://www.epa.gov/sites/default/files/2014-09/documents/ support_cc1_sodium_dwreport.pdf.]

U.S. Environmental Protection Agency, 2012, 2012 edition of the drinking water standards and health advisories: U.S. Environmental Protection Agency 822-S-12-001, 12 p. [Also available at https://rais.ornl.gov/documents/2012_ drinking_water.pdf.]

U.S. Geological Survey, 2012, The national field manual for the collection of water-quality data (version 7): U.S. Geological Survey Techniques and Methods, book 9, chaps. A1-A9, [variously paged], accessed July 2017 at h ttps://www.usgs.gov/mission-areas/water-resources/science/ national-field-manual-collection-water-quality-data-nfm?qtscience_center_objects $=0 \#$ qt-science_center_objects.

U.S. Geological Survey, 2019, USGS water data for the nation: U.S. Geological Survey National Water Information System database, accessed October 8, 2019, at https://doi.org/10.5066/F7P55KJN.

Wedel, A.A., 1932, Geologic structure of the Devonian strata of south-central New York: New York State Museum Bulletin 294, 74 p., 1 pl.

Williams, H.S., Tarr, R.S., and Kindle, E.M., 1909, Watkins Glen-Catatonk folio, New York: U.S. Geological Survey Folios of the Geologic Atlas 169, 6 sheets.

Williams, J.H., and Kappel, W.M., 2015, Hydrogeology of the Owego-Appalachian Elementary School geothermal fields, Tioga County, New York: U.S. Geological Survey Scientific Investigations Report 2015-5155, 29 p., accessed March 15, 2017, at https://doi.org/10.3133/sir20155155. 
Figure 7 

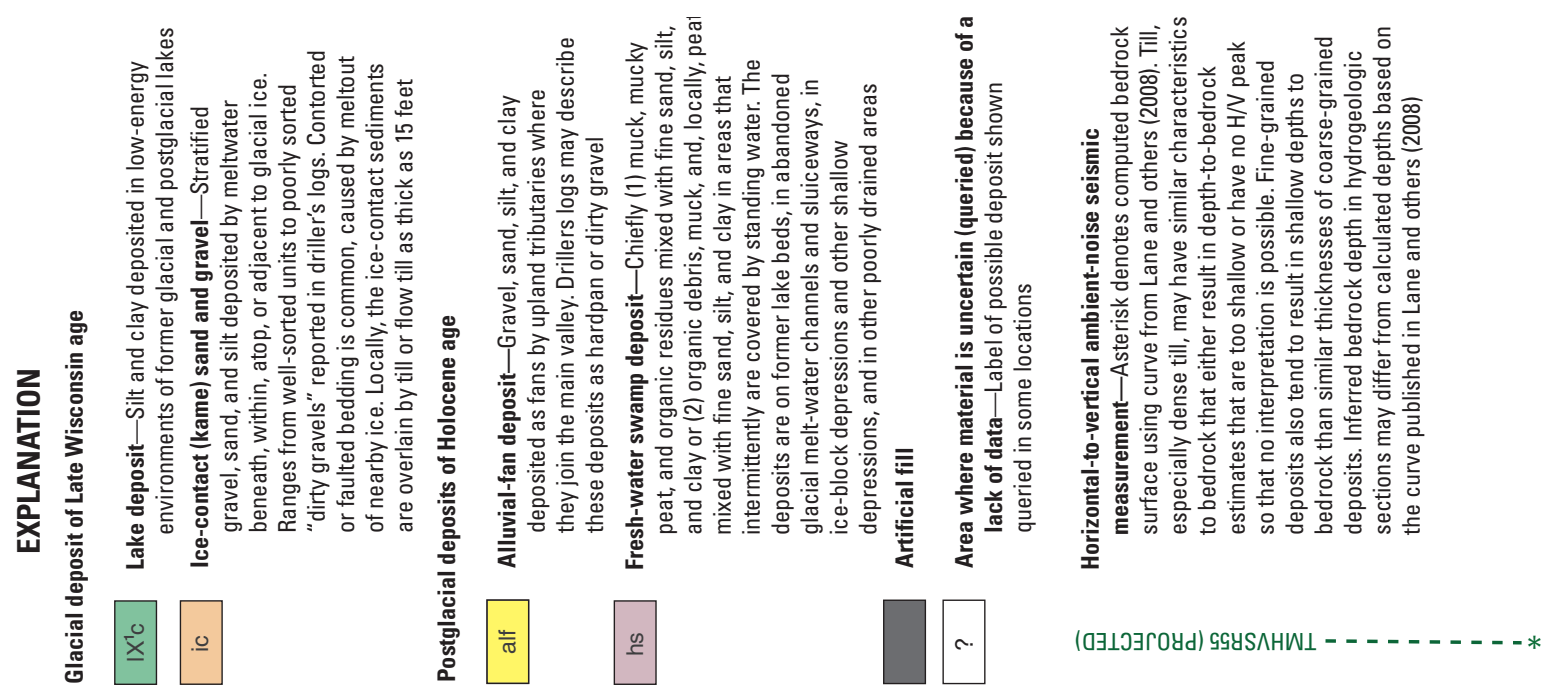

㸃
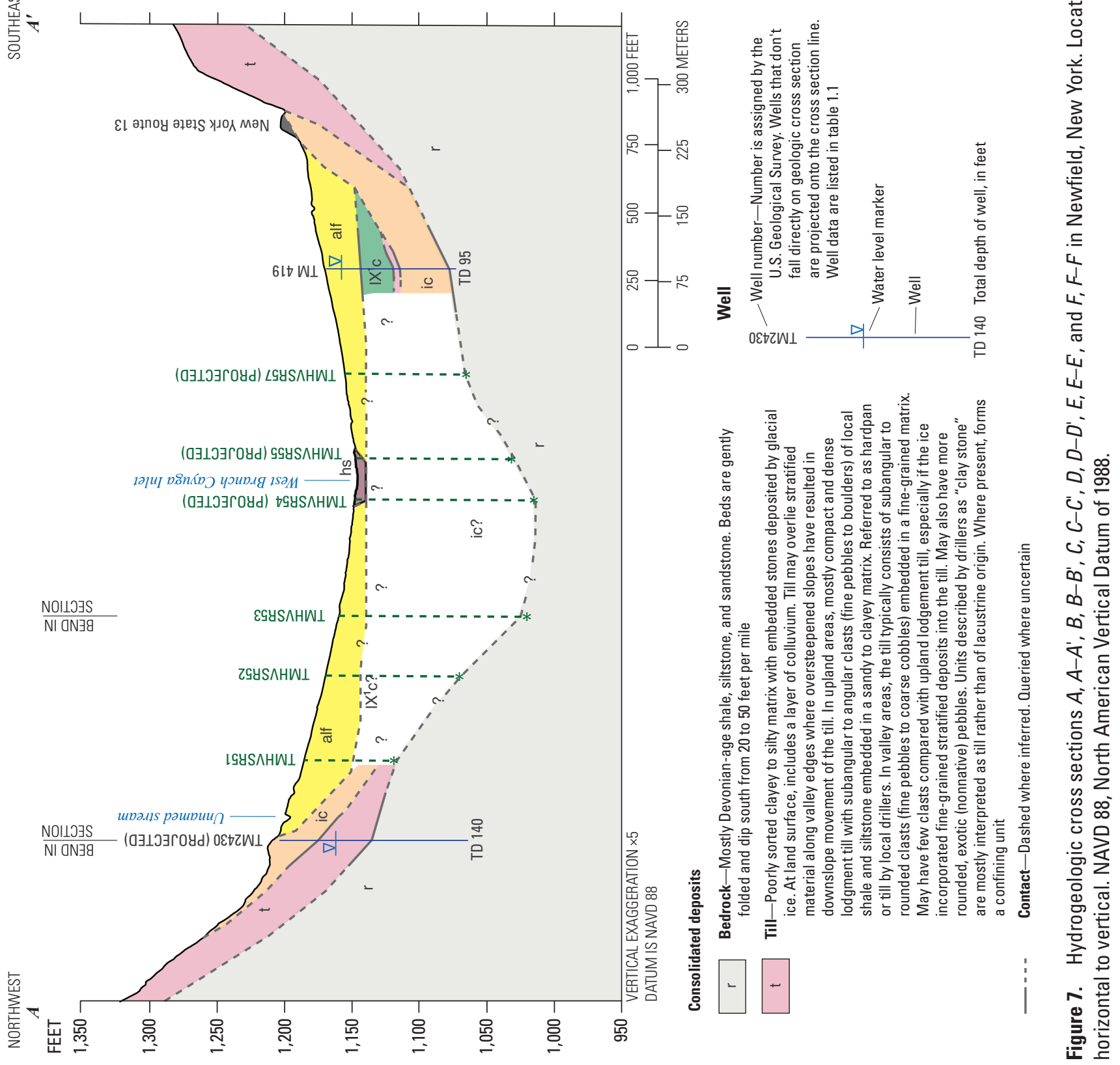

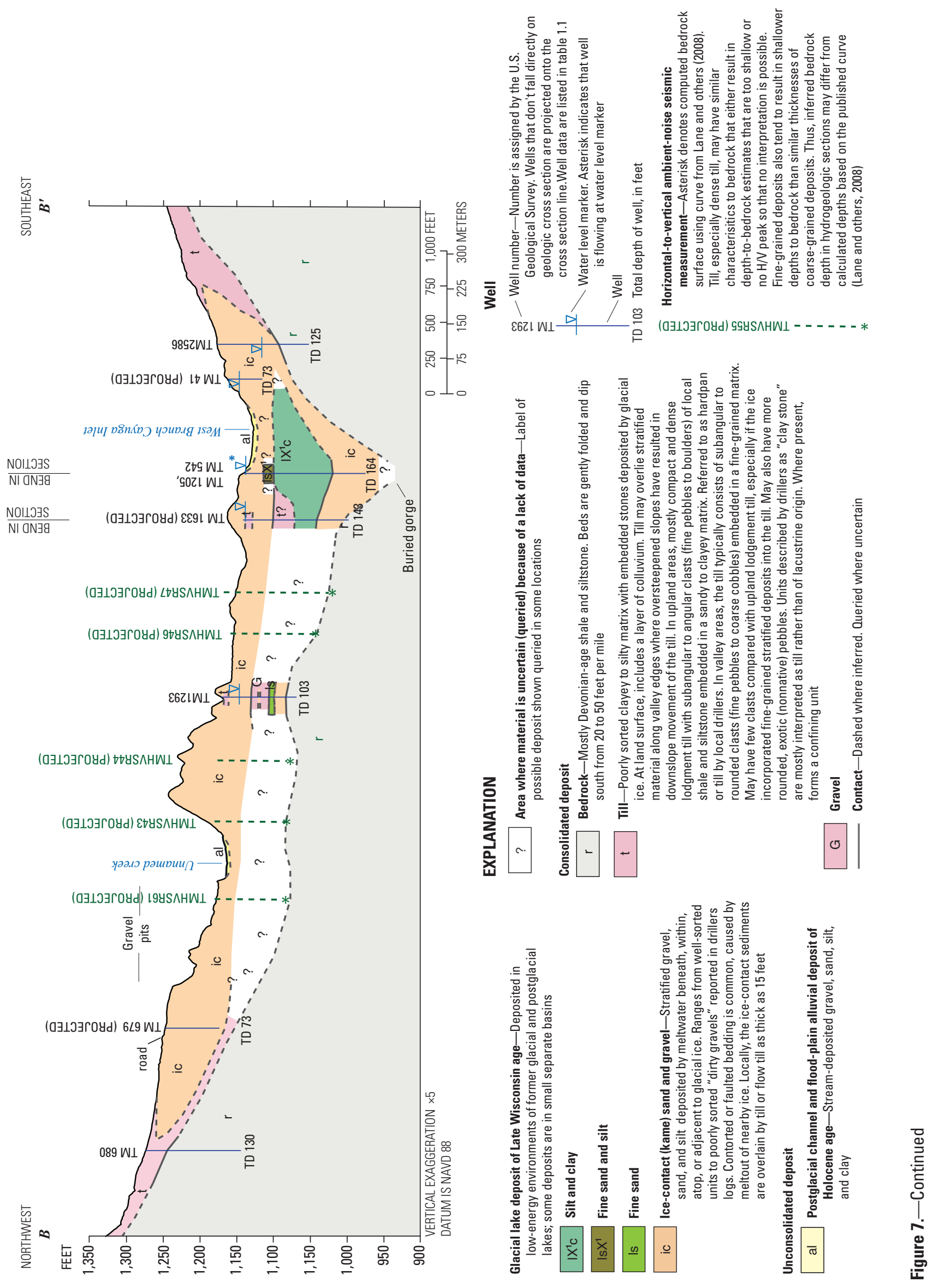

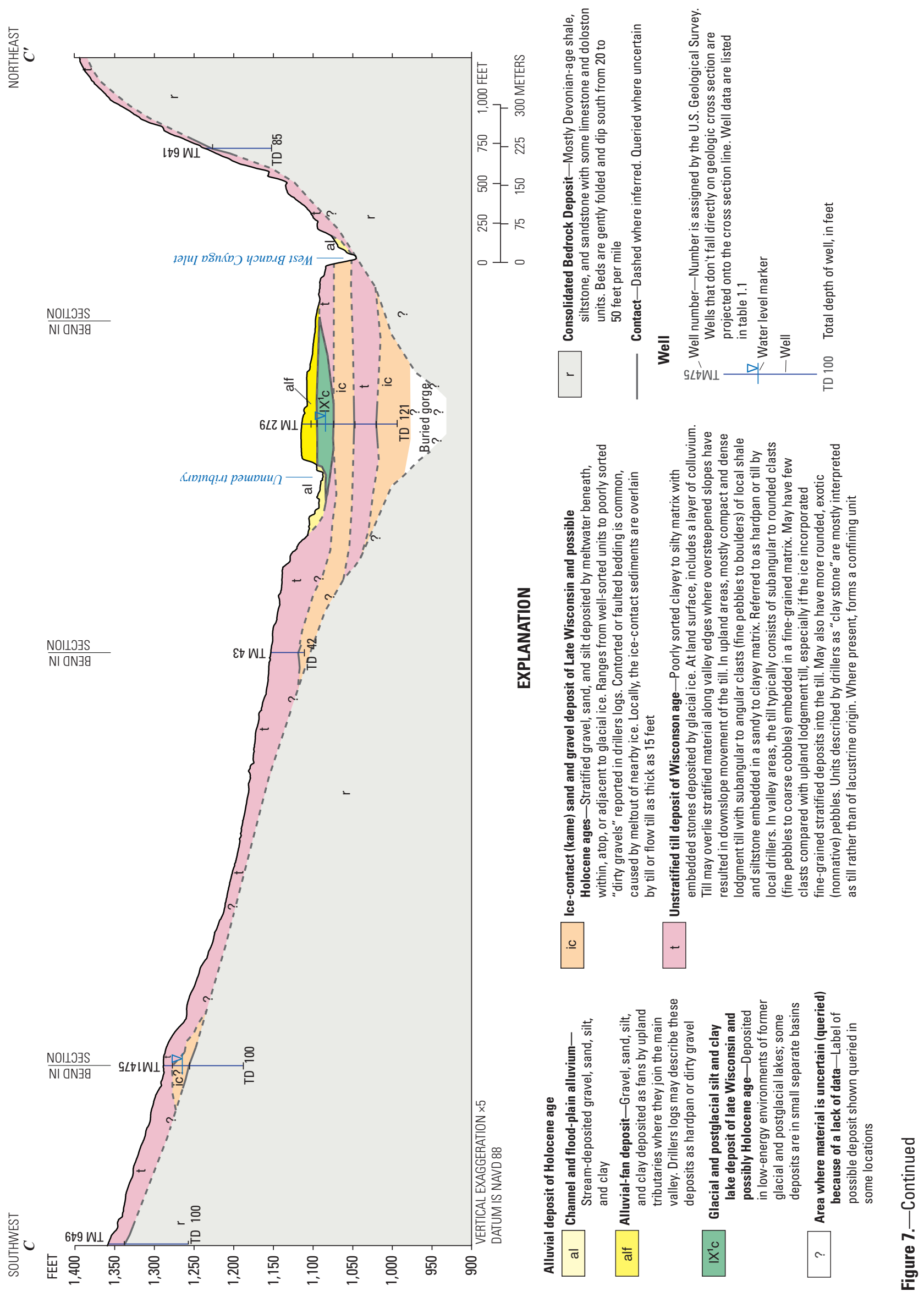
笕

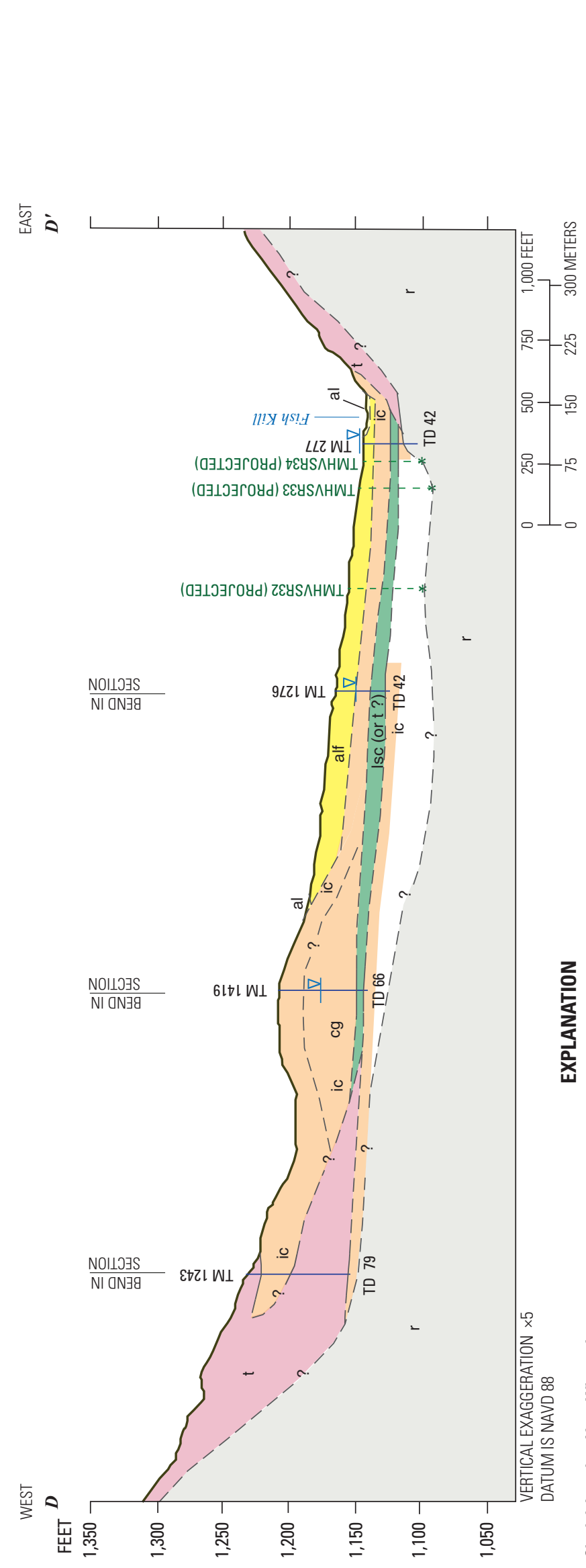

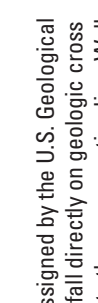

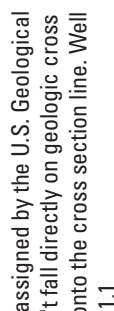

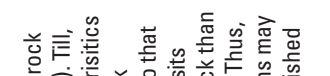

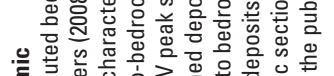

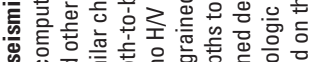

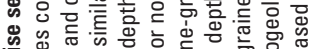

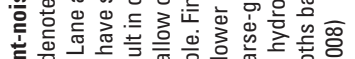

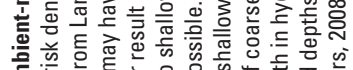

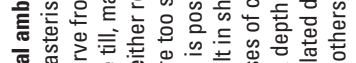

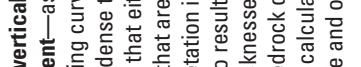

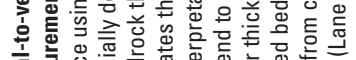

Imm

今े

E†ZIWL

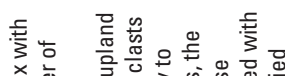

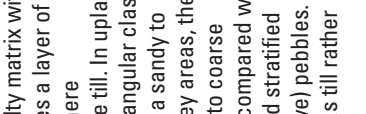

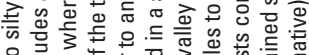

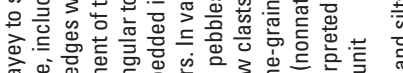

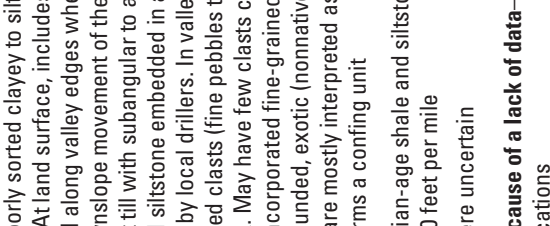

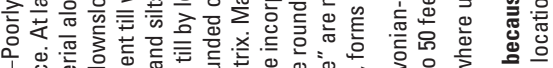

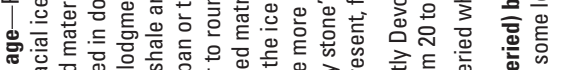

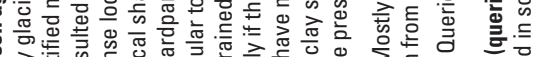

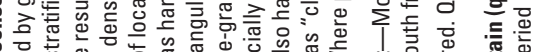

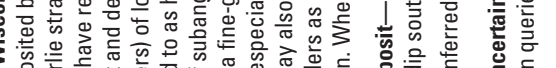

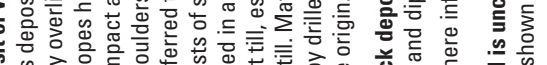

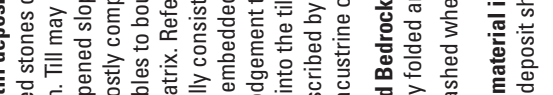

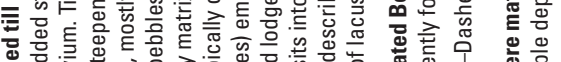

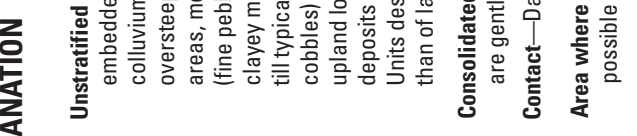

$-$
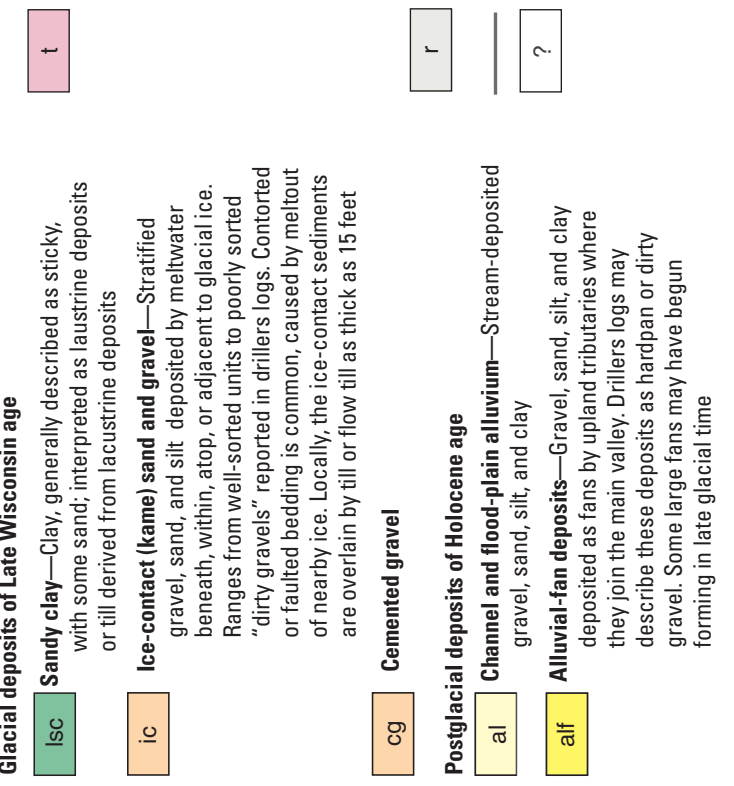

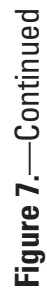


亭

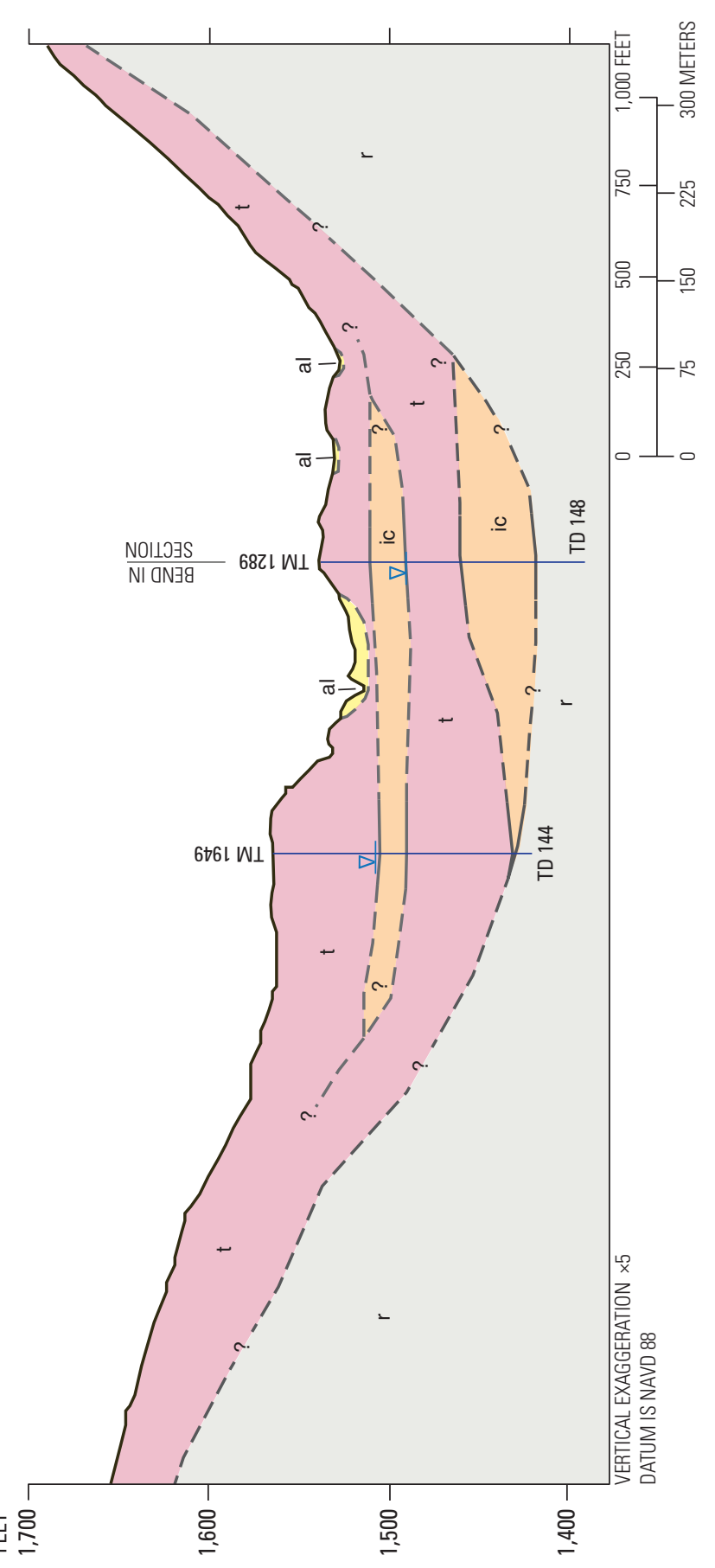

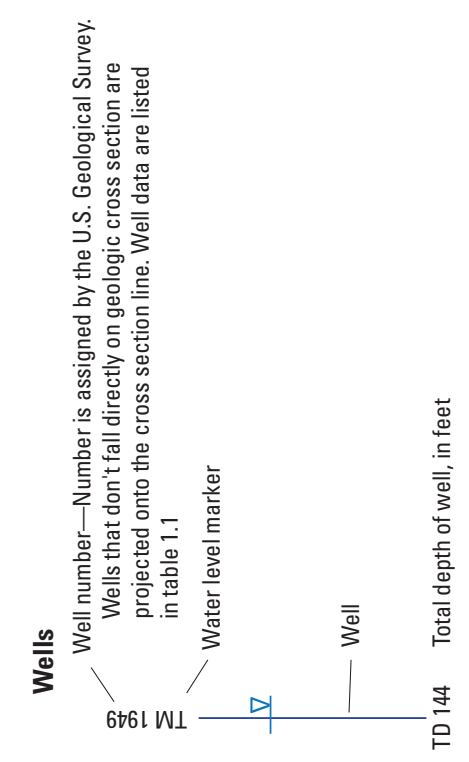

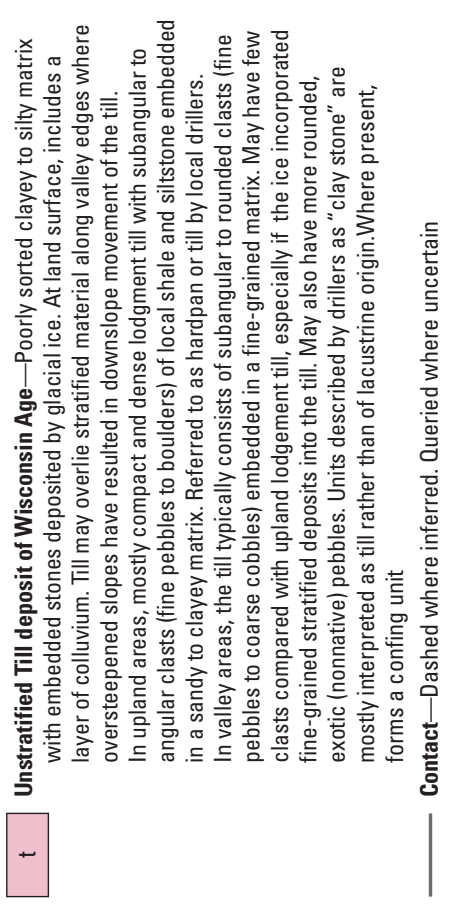




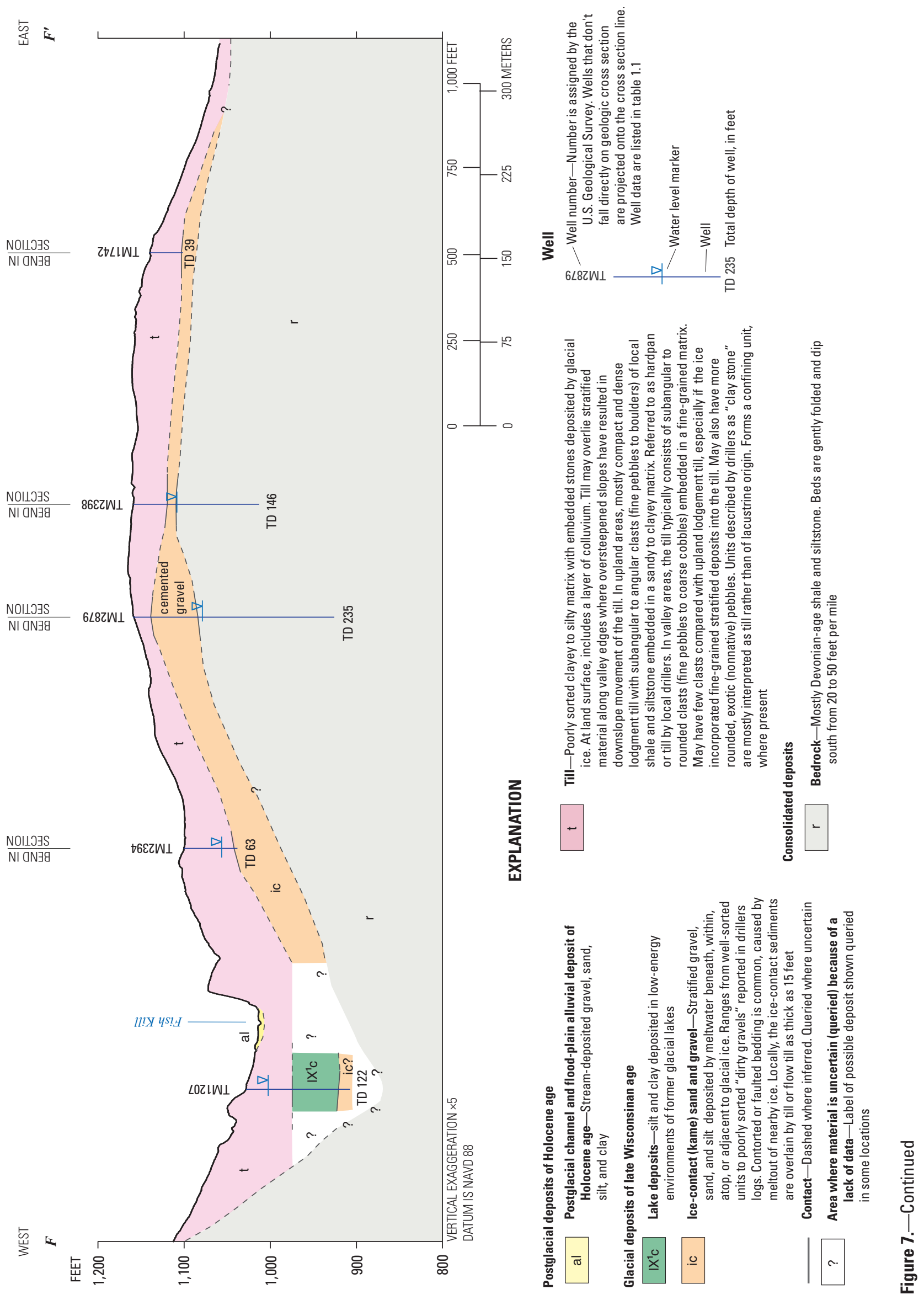


Appendixes 1-3 


\section{Appendix 1. Well Logs From Test Wells Drilled in the West Branch Cayuga Inlet and Fish Kill Aquifer in Newfield, New York}

Site name: TM 275 (well depth = $81 \mathrm{ft}$ )

Site ID: 421951076381001

Latitude: $42^{\circ} 19^{\prime} 50.71^{\prime \prime}$

Longitude: $076^{\circ} 38^{\prime} 09.94^{\prime \prime}$
Date completed: 05/02/2014

Drilling contractor: Berry Well Drilling, Trumansburg, NY

6 inch diameter steel casing

Casing below ground $=0.3 \mathrm{ft}$

Latitude and longitude measurement made by GPS (NAD83)

Elev. TOC $(6$ in. $)=1243.7 \mathrm{ft}$

Altitude relative

to NAVD 88

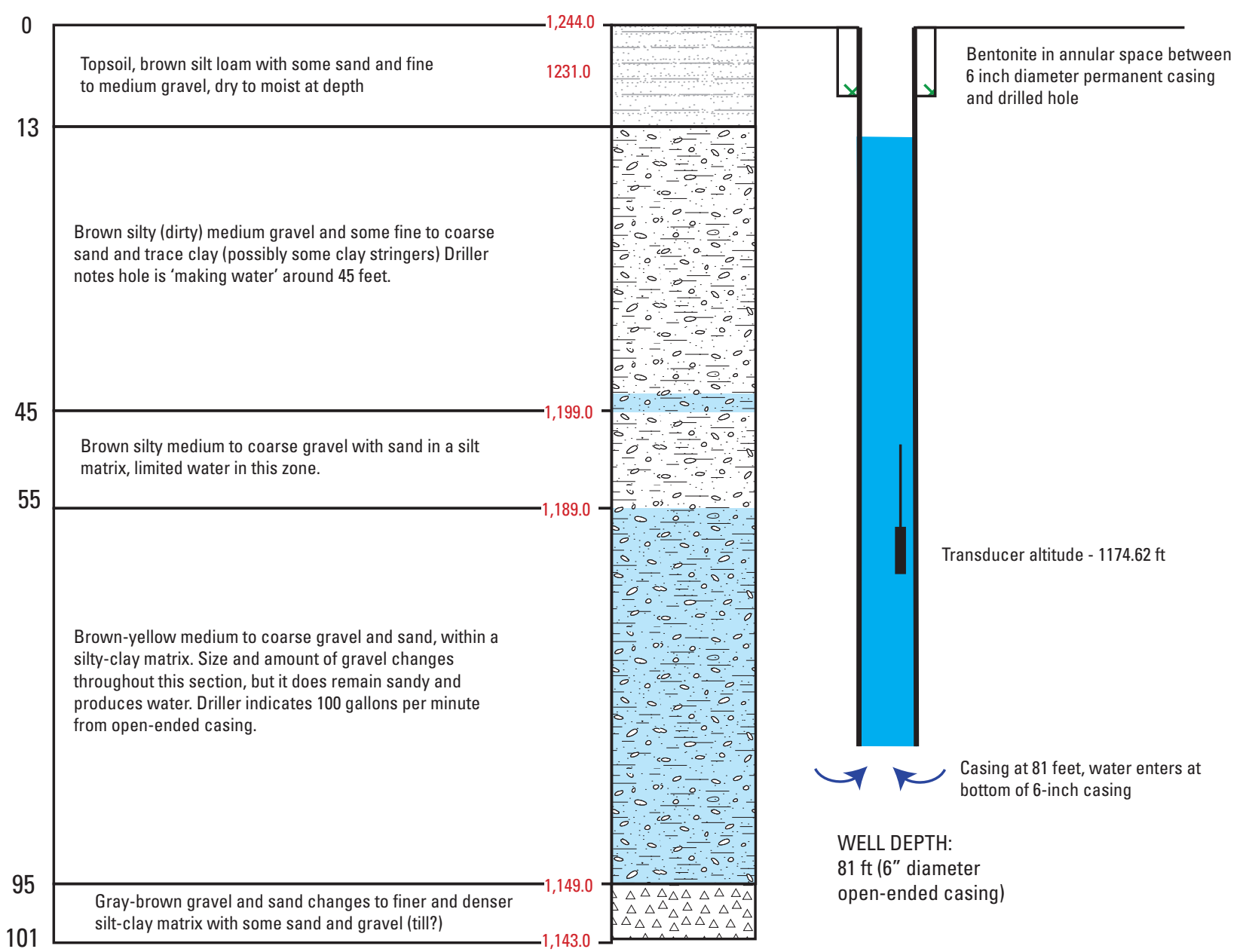

Bottom of hole $=101 \mathrm{ft}$

Figure 1.1. Well log for U.S. Geological Survey test well TM 275, Route 13 at Mazourek Road (north) in Newfield, New York, showing material and well information. 
Site name: TM 277 (well depth = $31 \mathrm{ft}$ )

Site ID: 422221076365001

Latitude: $42^{\circ} 22^{\prime} 21.20^{\prime \prime}$

Longitude: $076^{\circ} 36^{\prime} 50.09^{\prime \prime}$
Date completed: 05/06/2014

Drilling contractor: Berry Well Drilling, Trumansburg, NY

6 inch diameter steel casing

Casing above ground $=5.1 \mathrm{ft}$

Latitude and longitude measurement made by GPS (NAD83)

Elev. TOC $(6$ in. $)=1150.1 \mathrm{ft}$

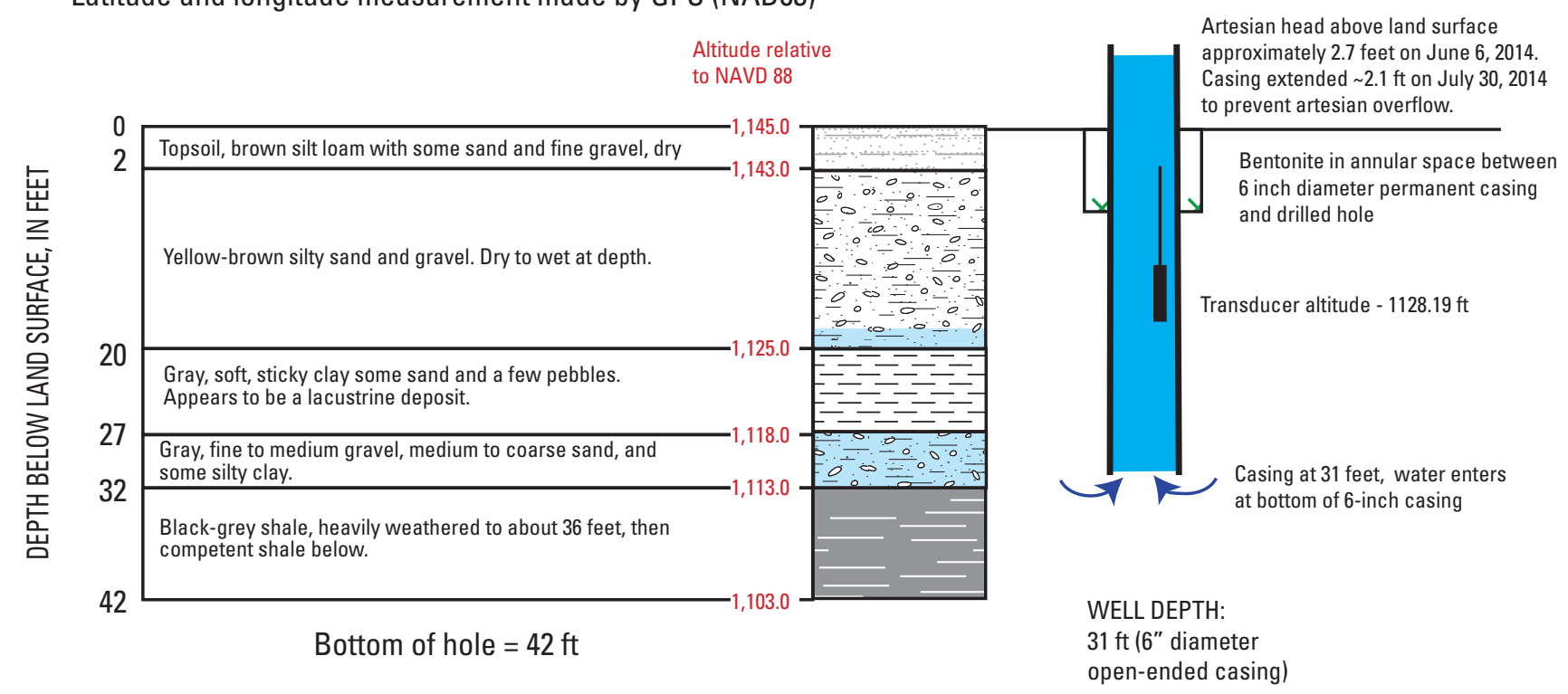

Figure 1.2. Well log for U.S. Geological Survey test well TM 277, Butternut Drive in Newfield, New York, showing material and well information. 
Site name: TM 279 (well depth = $101 \mathrm{ft}$ ) Site ID: 422130076355401

Latitude: $42^{\circ} 21^{\prime} 29.83^{\prime \prime}$

Longitude: $076^{\circ} 35^{\prime} 53.54^{\prime \prime}$
Date completed: 05/15/2014

Drilling contractor: Berry Well Drilling, Trumansburg, NY

6 inch diameter steel casing

Casing above ground $=3.1 \mathrm{ft}$

Latitude and longitude measurement made by GPS (NAD83)

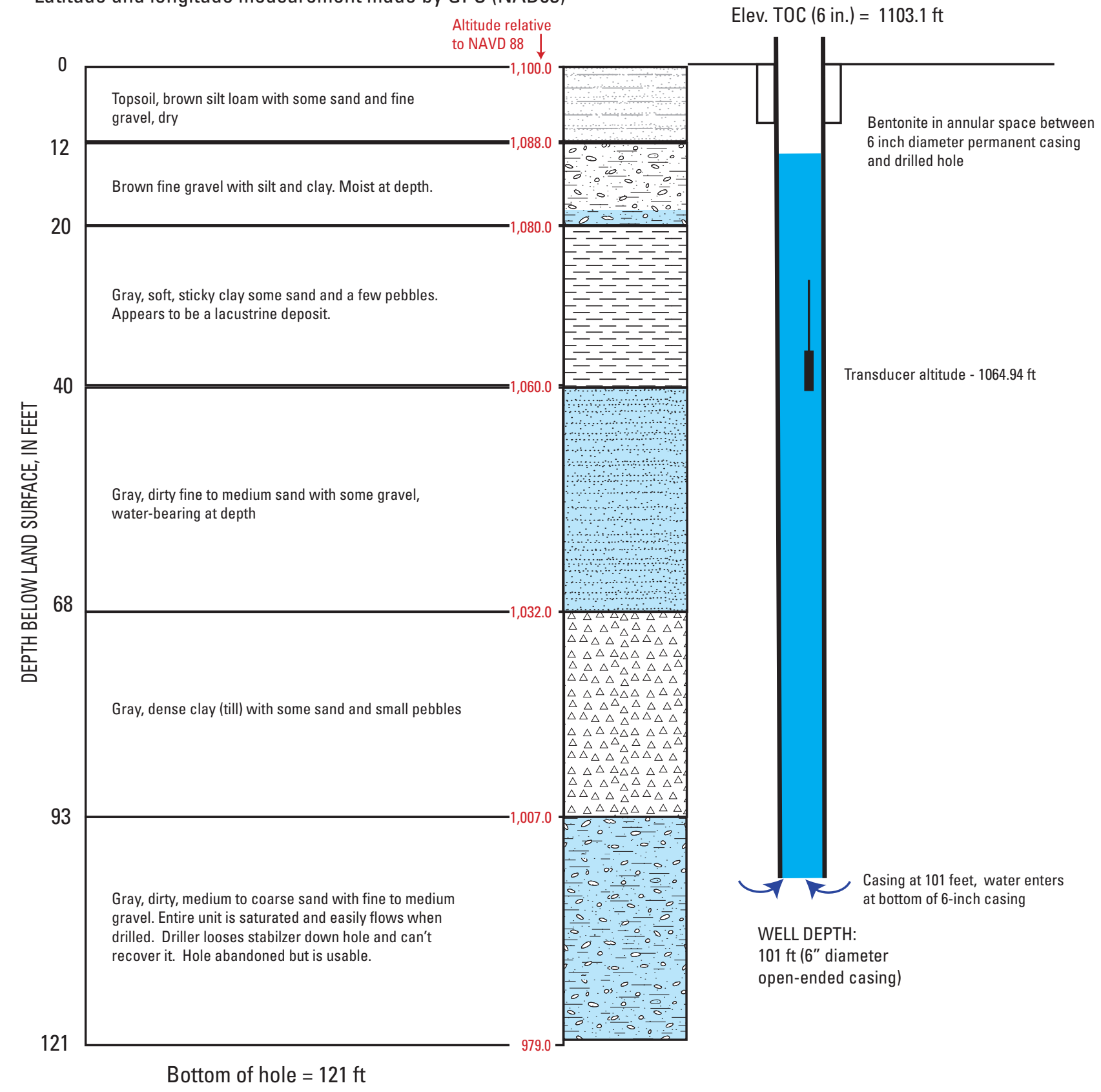

Figure 1.3. Well log for U.S. Geological Survey test well TM 279, Newfield School Bus Garage in Newfield, New York, showing material and well information. 
Site name: TM 418/923 (well depth $=101 \mathrm{ft}$ )

Site ID: 422157076372501 - TM 418 - $(78-77 \mathrm{ft})$

Site ID: 422157076372502 - TM 923 - (38-37 ft)

Latitude: $42^{\circ} 21^{\prime} 57.35^{\prime \prime}$

Longitude: $076^{\circ} 37^{\prime} 25.01^{\prime \prime}$

Latitude and longitude measurement made by GPS (NAD83)

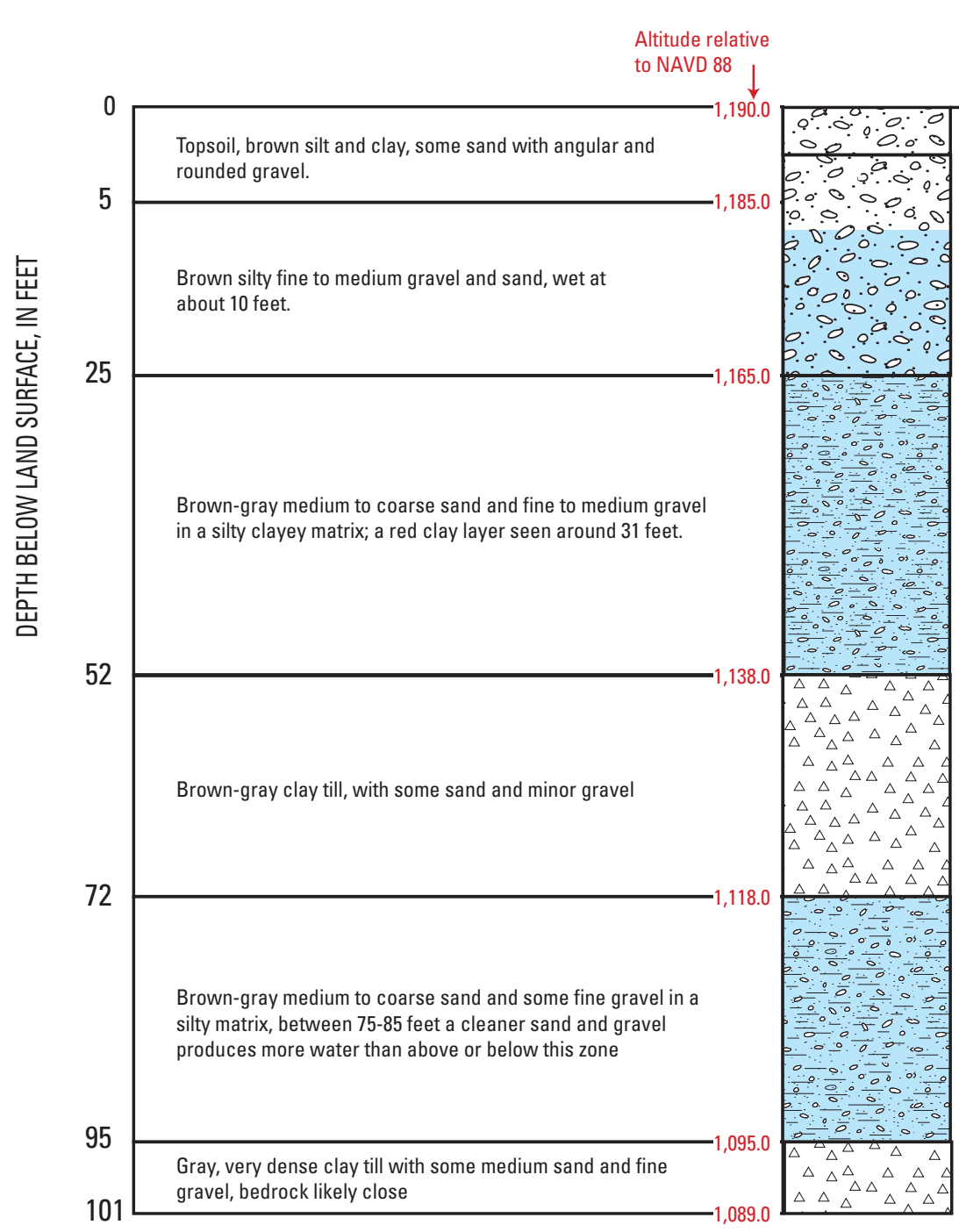

Bottom of hole $=101 \mathrm{ft}$
Date completed: 03/20/2015

K-packer installed 05/21/2015 - separates perforation zones

Drilling contractor: Frey Well Drilling, Alden, NY

6 inch diameter steel casing

Casing above ground $=3.9 \mathrm{ft}$

Elev. TOC (6 in.) $=1193.9 \mathrm{ft}$

Artesian head above land surface approximately 2 feet on March 24, 2015. Both zones artesian after K-packer installed May 21, 2015

Bentonite in annular space between 6 inch diameter permanent casing and drilled hole

Transducer altitude (shallow) - $1179.14 \mathrm{ft}$

Transducer altitude (deep) - $1167.30 \mathrm{ft}$

Casing perforated between 38-37 feet ( 3 sets of 5 perforations each) and yelds approximately 3 gallons per minute after development (TM 923)

Casing perforated between 78-77 feet ( 3 sets of 5 perforations each) and yelds approximately 20 gallons per minute after development (TM 418)

WELL DEPTH:

Casing seated in till, water enters at perforations above

$101 \mathrm{ft}$ (6" diameter

open-ended casing)

Figure 1.4. Well log for U.S. Geological Survey test wells TM 418 and TM 923, Trumbulls Corners Roads in Newfield, New York, showing material and well information. 
Site name: TM 419 (well depth = $90 \mathrm{ft}$ )

Site ID: 422037076373101

Latitude: $42^{\circ} 20^{\prime} 36.76^{\prime \prime}$

Longitude: $076^{\circ} 37^{\prime} 30.64^{\prime \prime}$
Date completed: 03/19/2015

Drilling contractor: Frey Well Drilling, Alden, NY

6 inch diameter steel casing

Casing above ground $=3.2 \mathrm{ft}$

Latitude and longitude measurement made by GPS (NAD83)

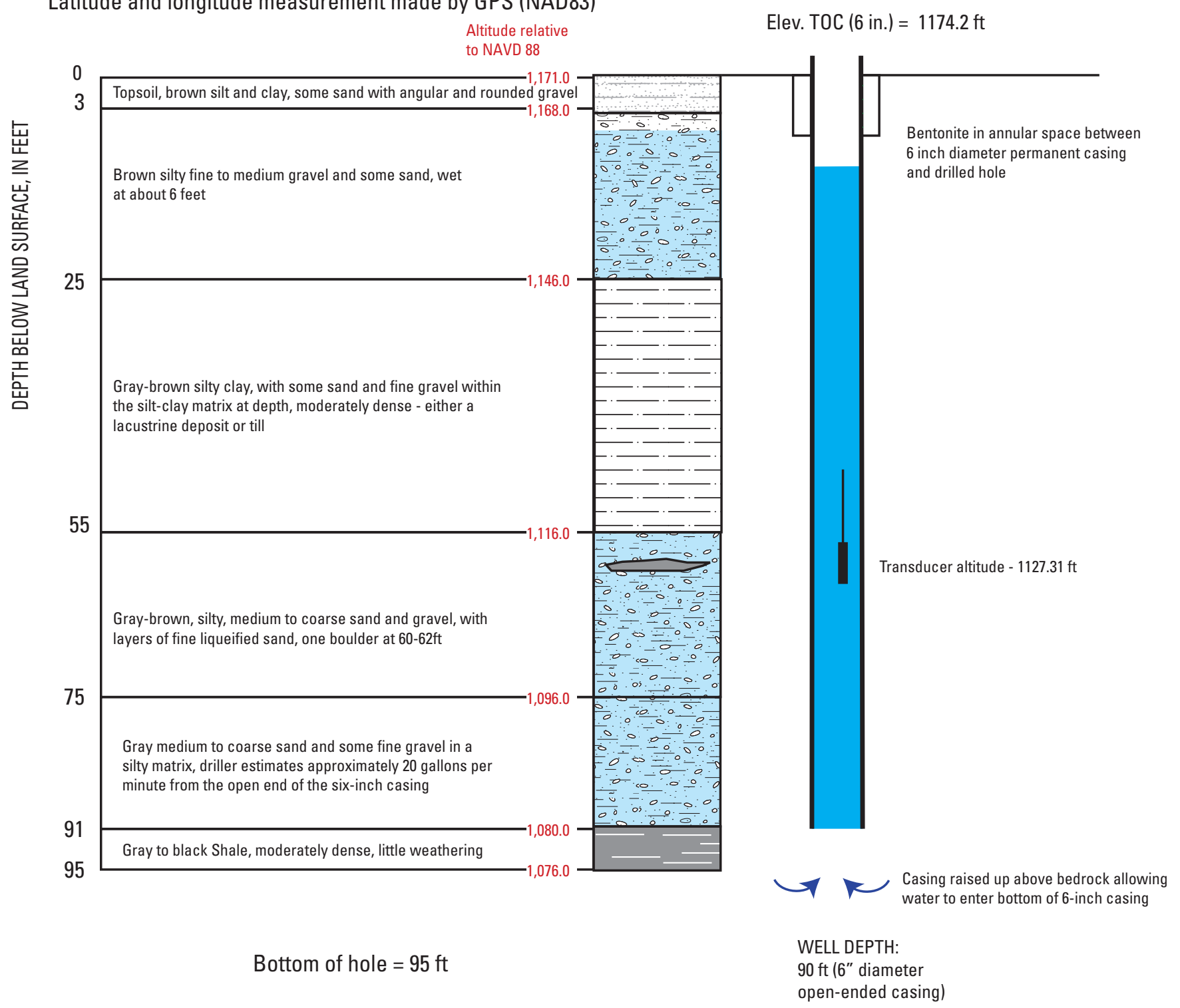

Figure 1.5. Well log for U.S. Geological Survey test well TM 419, Route 13 near Test Road in Newfield, New York, showing material and well information. 
Site name: TM 515 (well depth $=58 \mathrm{ft}$ )

Site ID: 422305076360601

Latitude: $42^{\circ} 23^{\prime} 05.32^{\prime \prime}$

Longitude: $076^{\circ} 36^{\prime} 06.39^{\prime \prime}$
Date completed: 03/16/2015

Drilling contractor: Frey Well Drilling, Alden, NY

6 inch diameter steel casing

Casing above ground $=3.8 \mathrm{ft}$

Latitude and longitude measurement made by GPS (NAD83)

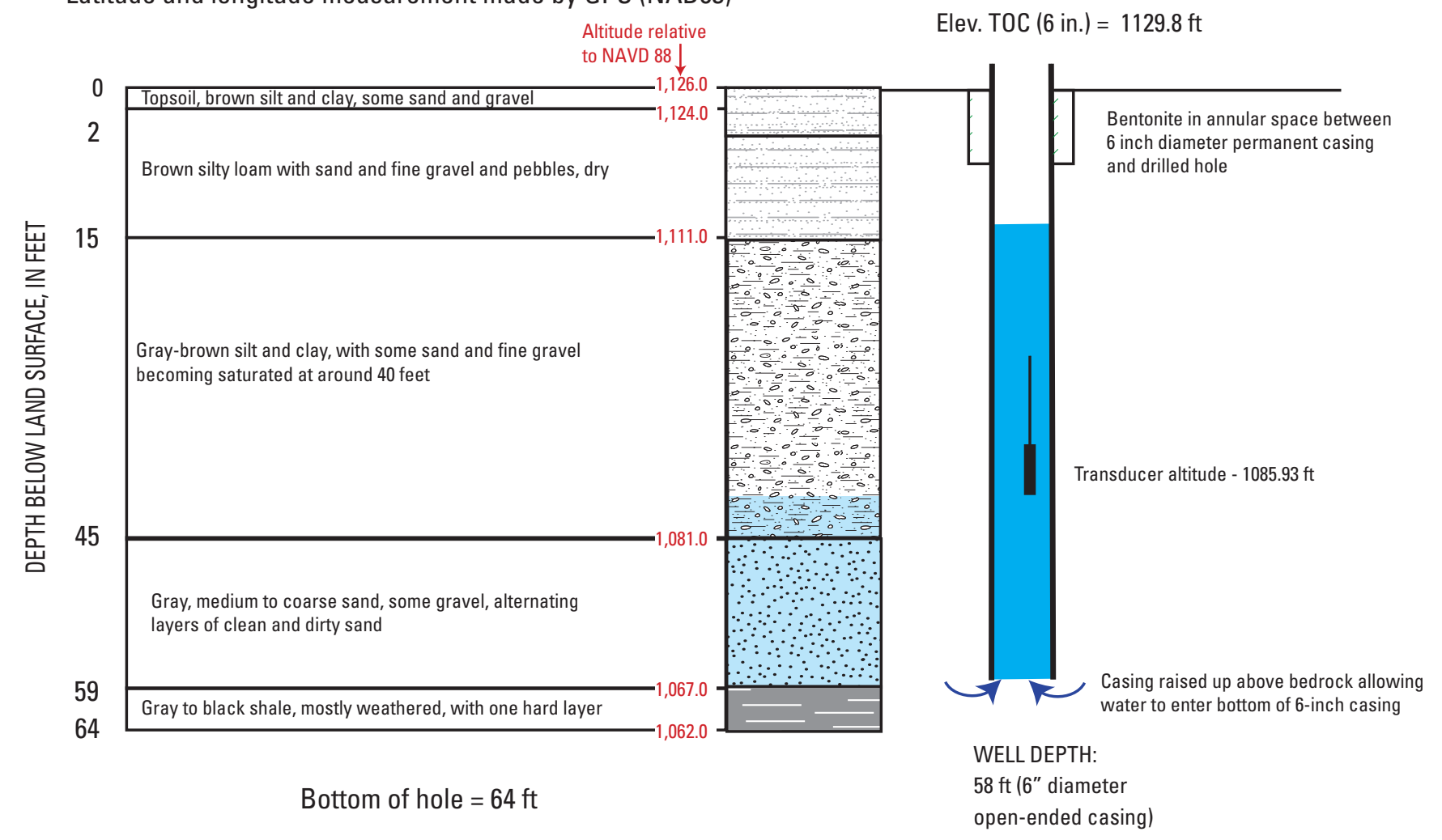

Figure 1.6. Well log for U.S. Geological Survey test well TM 515, Millard Hill Road in Newfield, New York, showing material and well information.

Table 1.1. Test wells drilled in the West Branch Cayuga Inlet and Fish Kill Valleys in Newfield, New York.

[U.S. Geological Survey (USGS) sites are from the National Water Information System (U.S. Geological Survey, 2019). ID, identification number; TM, well number in Tompkins County, assigned by the USGS]

\begin{tabular}{lcc}
\hline $\begin{array}{c}\text { USGS local well number } \\
\text { (fig. 4) }\end{array}$ & USGS site ID & $\begin{array}{c}\text { Well log } \\
\text { (figure) }\end{array}$ \\
\hline TM 275 & 421951076381001 & 1.1 \\
TM 277 & 422221076365001 & 1.2 \\
TM 279 & 422130076355401 & 1.3 \\
TM 418 & 422157076372501 & 1.4 \\
TM 923 & 422157076372502 & 1.4 \\
TM 419 & 422037076373101 & 1.5 \\
TM 515 & 422305076360601 & 1.6 \\
\hline
\end{tabular}

\section{Reference Cited}

U.S. Geological Survey, 2019, USGS water data for the nation: U.S. Geological Survey National Water Information System database, accessed October 8, 2019, at https://doi.org/10.5066/F7P55KJN. 


\section{Appendix 2. Test Well Hydrographs in the West Branch Cayuga Inlet and Fish Kill Valleys in Newfield, New York}
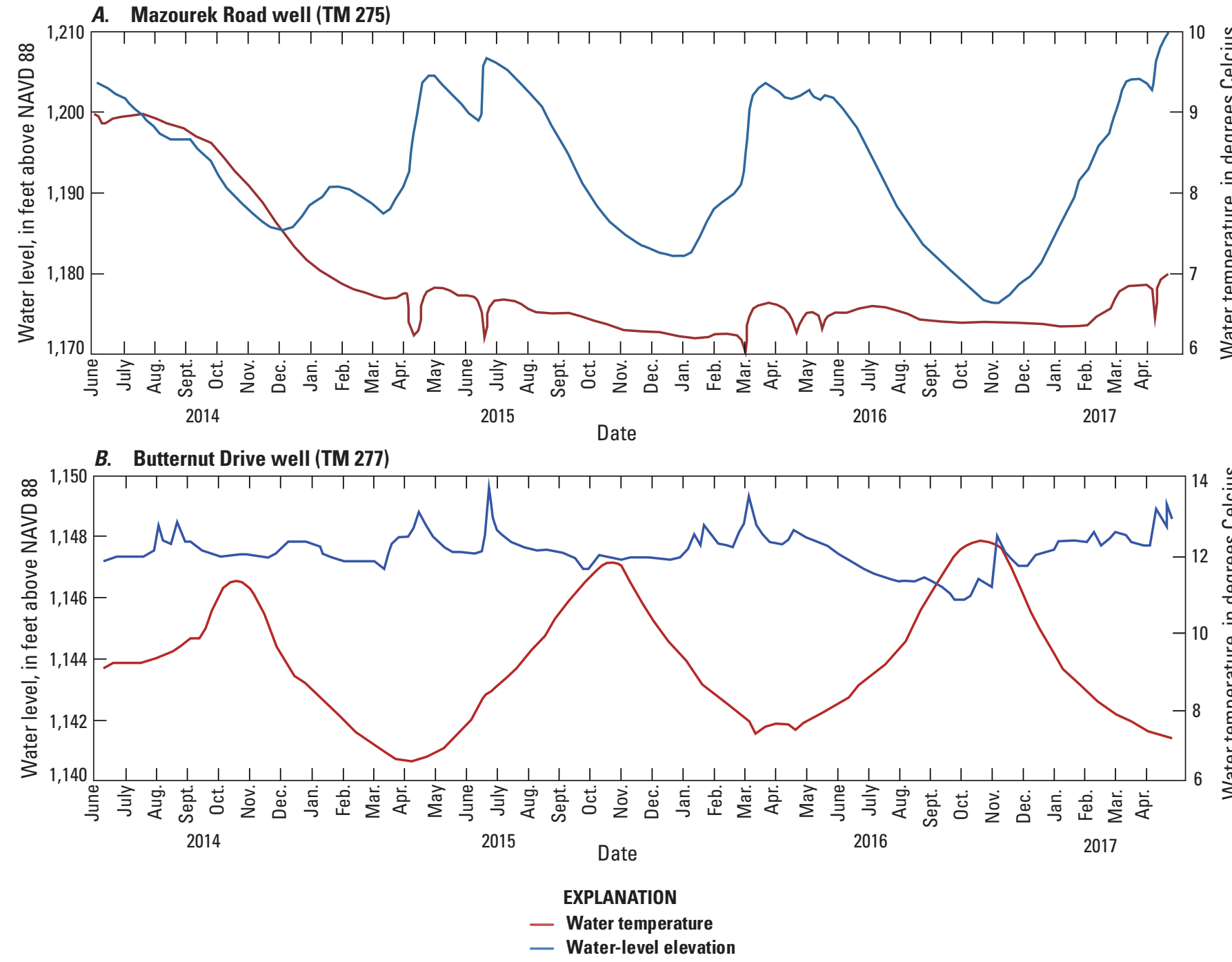

Figure 2.1. Hydrographs showing water-level elevation and water temperature at well $A$, TM 275, $B, \mathrm{TM} 277, C, \mathrm{TM} 279, D, \mathrm{TM} 289, E$, TM 417, F, TM 418, G, TM 923, H, TM 419, and I, TM 515 in Newfield, New York. Data are from the National Water Information System (U.S. Geological Survey, 2019). NAVD 88, North American Vertical Datum of 1988. 

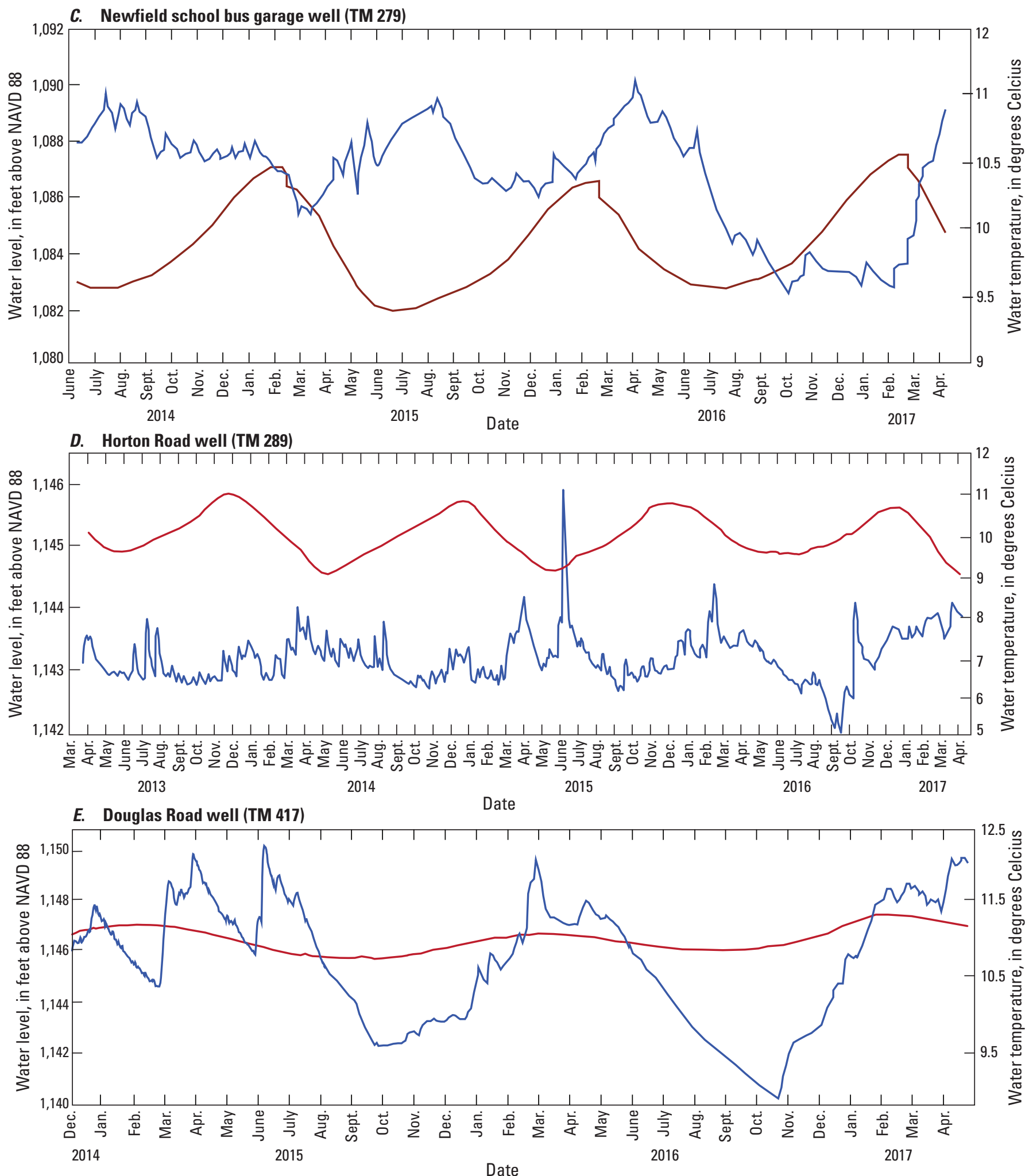

EXPLANATION

- Water temperature

- Water-level elevation

Figure 2.1.-Continued 
F. Trumbulls Corners Road well F1—deep (TM 418)

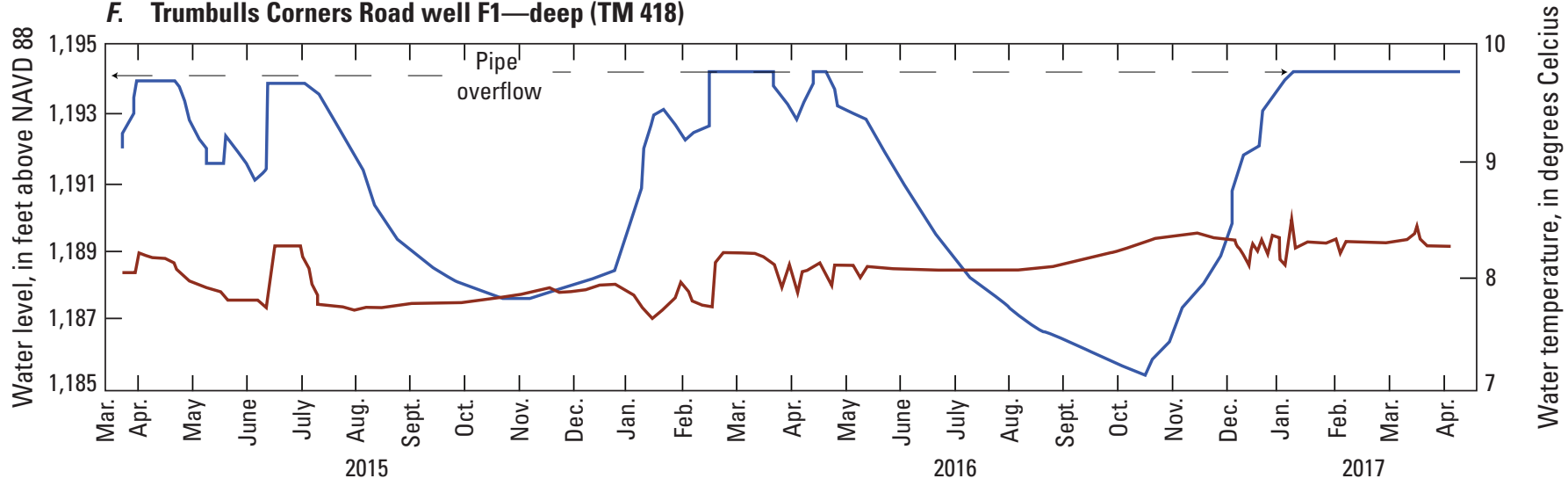

Date
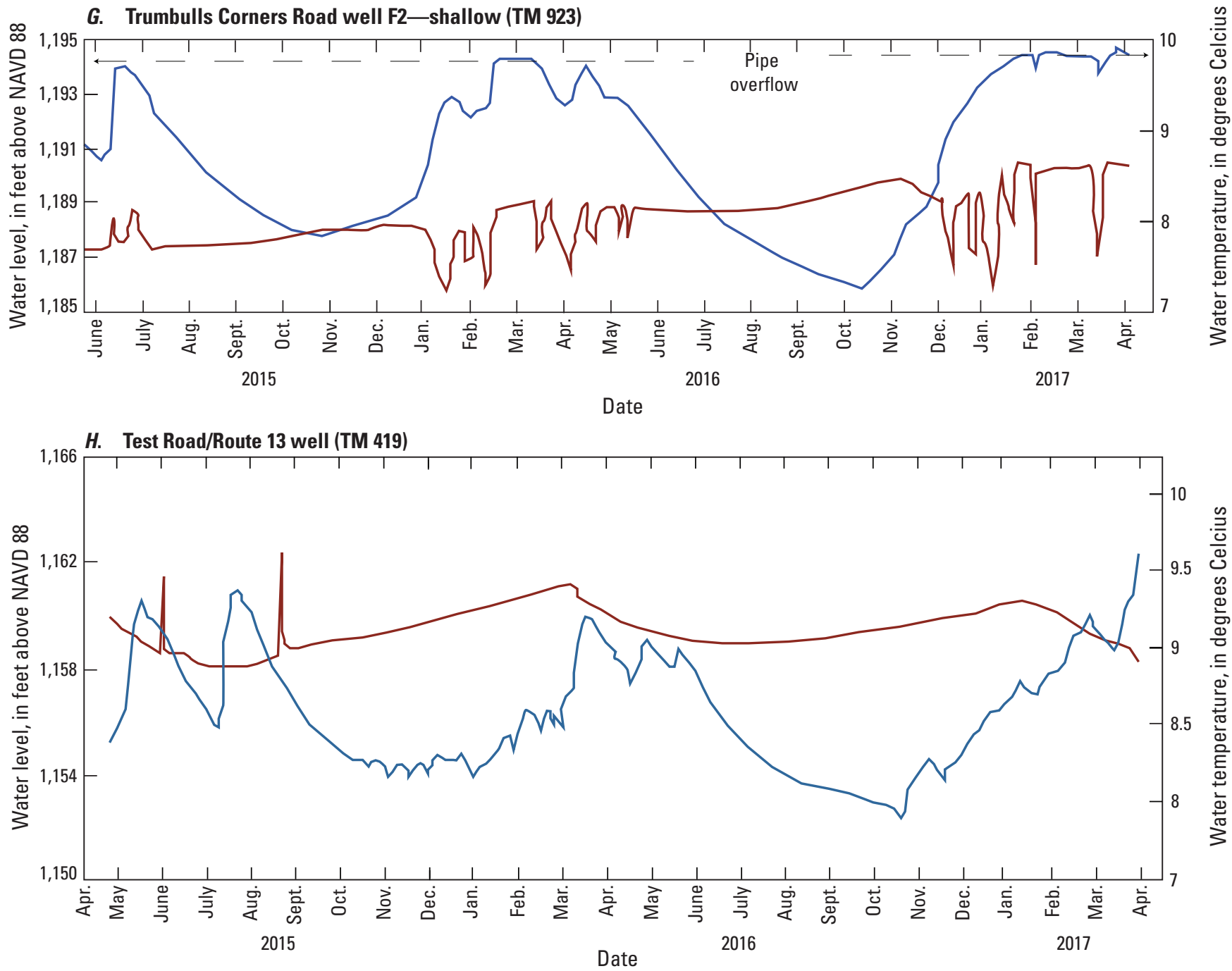

EXPLANATION

- Water temperature

- Water-level elevation

Figure 2.1.-Continued 

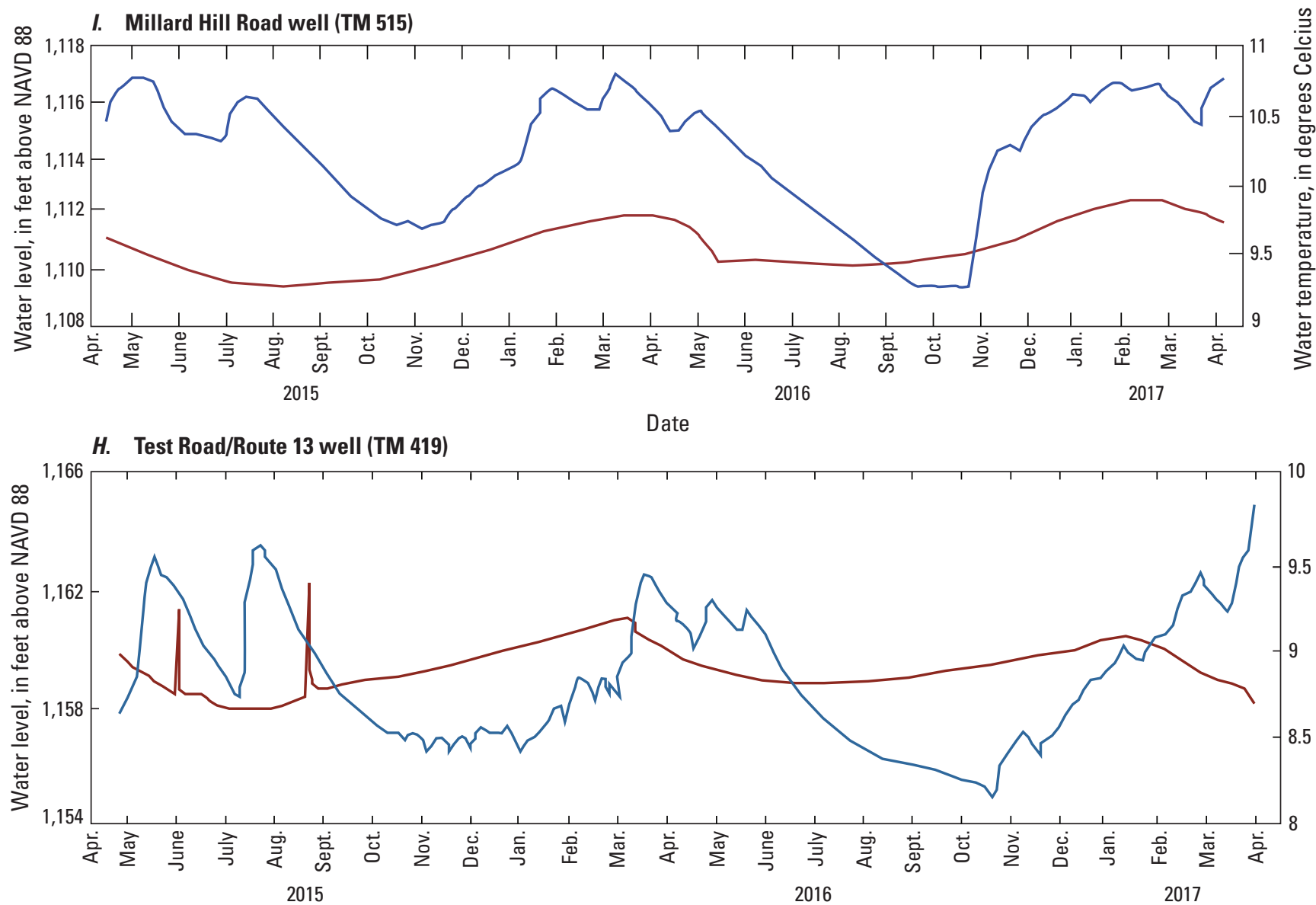

Date

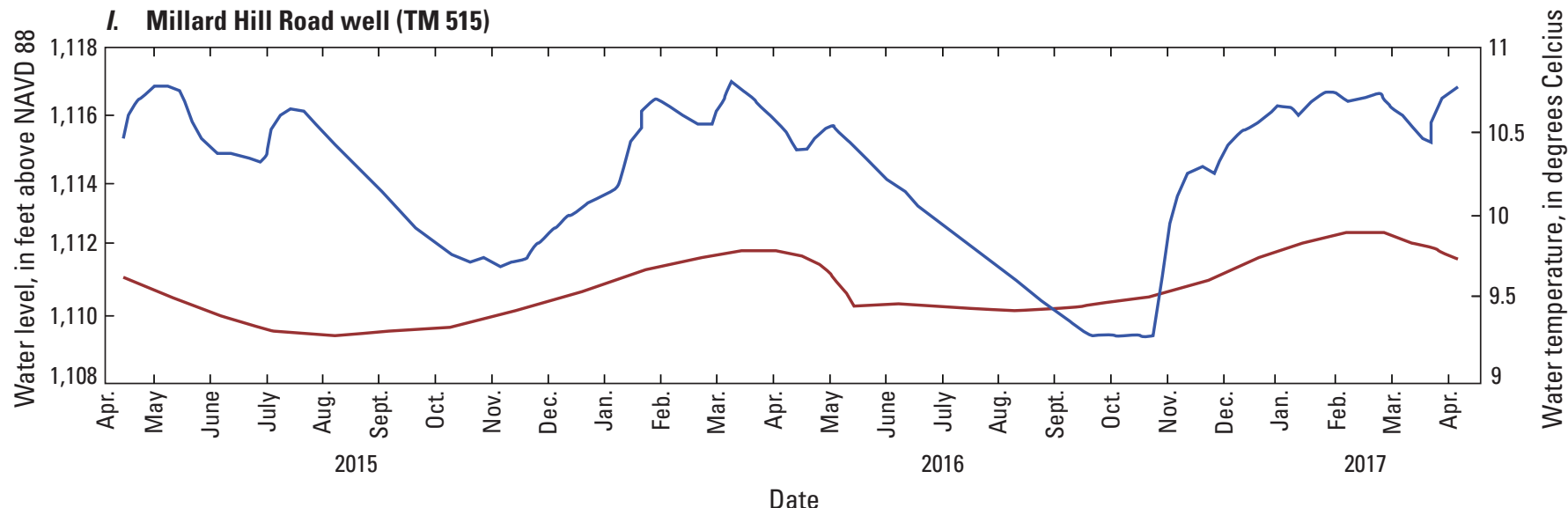

Figure 2.1.-Continued 
Table 2.1. Wells with water level and temperature recorders in the West Branch Cayuga Inlet and Fish Kill Valleys in Newfield, New York.

[USGS, U.S. Geological Survey; ID, identification number; NWIS, National Water Information System (U.S. Geological Survey, 2019); TM, well number in Tomkins County, assigned by the USGS]

\begin{tabular}{|c|c|c|c|}
\hline $\begin{array}{l}\text { USGS local } \\
\text { well number } \\
\text { (fig. 4) }\end{array}$ & USGS site ID & $\begin{array}{c}\text { Well log } \\
\text { (figure) }\end{array}$ & Link to NWIS \\
\hline TM 275 & 421951076381001 & $2.1 A$ & https://waterdata.usgs.gov/nwis/inventory/?site_no $=421951076381001$ \\
\hline TM 277 & 422221076365001 & $2.1 A$ & https://waterdata.usgs.gov/nwis/inventory/?site_no $=422221076365001$ \\
\hline TM 279 & 422130076355401 & $2.1 \mathrm{~A}$ & https://waterdata.usgs.gov/nwis/inventory/?site_no $=422130076355401$ \\
\hline TM 289 & 422242076365901 & $2.1 B$ & https://waterdata.usgs.gov/nwis/inventory/?site_no $=422242076365901$ \\
\hline TM 418 & 422157076372501 & $2.1 B$ & https://waterdata.usgs.gov/nwis/inventory/?site_no $=422157076372501$ \\
\hline TM 923 & 422157076372502 & $2.1 C$ & https://waterdata.usgs.gov/nwis/inventory/?site_no $=422157076372502$ \\
\hline TM 419 & 422037076373101 & $2.1 C$ & https://waterdata.usgs.gov/nwis/inventory/?site_no $=422037076373101$ \\
\hline TM 515 & 422305076360601 & $2.1 C$ & https://waterdata.usgs.gov/nwis/inventory/?site_no $=422305076360601$ \\
\hline
\end{tabular}

\section{Reference Cited}

U.S. Geological Survey, 2019, USGS water data for the nation: U.S. Geological Survey National Water Information System database, accessed October 8, 2019, at https://doi.org/10.5066/F7P55KJN. 


\section{Appendix 3. Groundwater Samples Collected in the West Branch Cayuga Inlet and Fish Kill Valleys in Newfield, New York}

Table 3.1. Physical properties and concentrations of common ions, nutrients, radiochemical properties, and dissolved gases in groundwater samples from confined aquifers in the West Branch Cayuga Inlet and Fish Kill Creek Valleys, Newfield, Tompkins County, New York.

[Available for download as a comma-separated value (CSV) table at https://doi.org/10.3133/sir20215064. Data are from the National Water Information System (U.S. Geological Survey, 2019). Locations of sites shown on figure 4. Footnotes: a, U.S. Environmental Protection Agency (EPA) maximum contaminant level; b, EPA maximum contaminant level goal; c, New York State Department of Health maximum contaminant level; d, EPA secondary maximum contaminant level; e, EPA drinking-water advisory taste threshold; f, Chlorofluorocarbons (CFCs) are used to estimate groundwater age, concentration values represent the median derived from three values, or the average derived from two values, reported by the U.S. Geological Survey (USGS) Reston Groundwater Dating Laboratory; $\mathrm{g}$, A system must determine compliance with the maximum contaminant level for beta particle and photon radioactivity by using the following calculation described in U.S. Environmental Protection Agency (2012), as follows: [pCi/L found in sample (from laboratory results) / pCi/L-equivalent of 4 millirem of exposure $]=$ fraction of the maximum 4 millirem per year exposure limit; $\mathrm{h}$, Action level recommended by the Office of Surface Mining Reclamantion and Enforcement. Parm code, National Water Information System (NWIS) parameter code; S\&G, sand and gravel; conf, confined; unconf, unconfined; ?, no well log exists but assumed to be confined; $\mathrm{ft}$, foot; $\mathrm{mg} / \mathrm{L}$, milligram per liter; $\mu \mathrm{S} / \mathrm{cm}$ at $25^{\circ} \mathrm{C}$, microsiemens per centimeter at 25 degrees Celsius; ${ }^{\circ} \mathrm{C}$, degrees Celsius; pCi/L, picocurie per liter; e, estimated; R, radiochemistry nondetected, result below sample specific critical level; mrem, millirem; <, less than; XX, no data]

Table 3.2. Concentrations of trace elements in groundwater samples from confined aquifers in the West Branch Cayuga Inlet and Fish Kill Creek Valleys, Newfield, Tompkins County, New York.

[Available for download as a comma-separated value (CSV) table at https://doi.org/10.3133/sir20215064. Data are from the National Water Information System (U.S. Geological Survey, 2019). Footnotes: a, U.S. Environmental Protection Agency (EPA) maximum contaminant level; b, EPA maximum contaminant level goal; c, New York State Department of Health maximum contaminant level; d, EPA secondary maximum contaminant level; e, EPA treatment technique. Parm code, National Water Information System (NWIS) parameter code; USGS, U.S. Geological Survey; S\&G, sand and gravel; conf, confined; ?, no well log exists but assumed to be confined; unconf, unconfined; $\mu \mathrm{g} / \mathrm{L}$, microgram per liter; $<$, less than; - , not applicable]

\section{Reference Cited}

U.S. Geological Survey, 2019, USGS water data for the nation: U.S. Geological Survey National Water Information System database, accessed October 8, 2019, at https://doi.org/10.5066/F7P55KJN. 
For more information, contact

Director, New York Water Science Center

U.S. Geological Survey

425 Jordan Road

Troy, NY 12180-8349

dc_ny@usgs.gov

or visit our website at

https://www.usgs.gov/centers/ny-water

Publishing support provided by the Pembroke and

Reston Publishing Service Centers. 


\section{$\frac{\mathbb{2}}{\mathrm{C}}$}

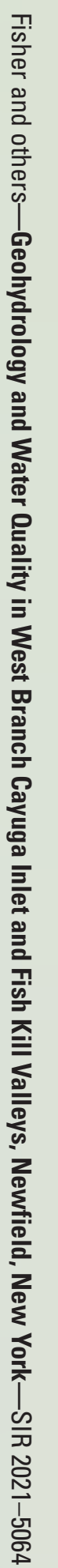

